\title{
Tectonic synthesis of the Olympic Mountains segment of the Cascadia wedge, using two-dimensional thermal and kinematic modeling of thermochronological ages
}

\author{
Geoffrey E. Batt ${ }^{1}$ and Mark T. Brandon \\ Department of Geology and Geophysics, Yale University, New Haven, Connecticut, USA \\ Kenneth A. Farley \\ Division of Geological and Planetary Sciences, California Institute of Technology, Pasadena California, USA \\ Mary Roden-Tice \\ Center for Earth and Environmental Science, State University of New York at Plattsburgh, Plattsburgh, New York, USA
}

\begin{abstract}
A fully coupled two-dimensional kinematic and thermal model of a steady state accretionary wedge, constrained by an extensive data set of fission track and (U-Th)/He ages for apatite and zircon, is here used to investigate the development of the Olympic Mountains segment of the Cascadia accretionary wedge. The model has two main free parameters: $\dot{\varepsilon}_{\text {max }}$, the maximum rate of erosion for a generic erosion function operating at the top of the wedge, and $\alpha$, the distribution of sedimentary accretion into the wedge. The best fit values for $\dot{\varepsilon}_{\max }$ and $\alpha$ and their confidence limits are determined through an iterative search of parameter space. This study represents the first time that such inversion methods have been used to quantify the thermalkinematic evolution of an accretionary wedge. Our results suggest that horizontal transport plays an important role in the exhumation trajectories experienced by material passing through the Cascadia wedge. At a $95 \%$ confidence interval, 80 to $100 \%$ of the sedimentary sequence from the subducting Juan de Fuca Plate has been accreted at the front of the wedge offshore of the Olympics over the past 14 m.y. This frontally accreted material must then traverse the entire width of the wedge prior to its eventual exposure in the Olympic forearc high. Assessed in this twodimensional framework, the fission track and (U-Th)/He age data sets from the Olympic Mountains are all best fit by $\dot{\varepsilon}_{\max }$ of $0.9-1.0 \mathrm{~mm} \mathrm{yr}^{-1}$, despite variation in the timescales relevant to the three chronometers. This result supports the hypothesis that the Olympic Mountains segment of the Cascadia accretionary wedge has been in a flux steady-state since $-14 \mathrm{Ma}$. The demonstration of a flux balance across the Cascadia margin also suggests that margin-parallel transport has not had a significant role in driving uplift of the Olympic Mountains.
\end{abstract}

\section{Introduction}

The Olympic Mountains in northwest Washington are the topographically highest and most deeply exhumed segment of the coastal mountain range extending along the Cascadia margin from the Klamath Mountains of northern California to the Insular Range of Vancouver Island (Plate. 1). This high separates a relatively continuous forearc depression to the east (Willamette, Puget, and Georgia lowlands) from the accretionary wedge to the west. Dickinson and Seely [1979] refer to this arrangement as a ridged forearc and note that it is typical of mature continental convergent margins and ancient subduction complexes around the world. \footnotetext{
Egham, England, UK

Copyright 2001 by the American Geophysical Union.

Paper number 2001JB000288.

0148-0227/01/2001JB000288\$09.00
}

'Now at Geology Department, Royal Holloway University of London,
Brandon and Vance [1992] and Brandon et al. [1998] use zircon and apatite fission track data from the Olympic subduction complex to investigate the late Cenozoic evolution of the Olympic Mountains. Fission track ages record the length of time that radiation damage caused by the spontaneous fission of ${ }^{238} \mathrm{U}$ has been accumulating in the dated mineral [e.g., Price and Walker, 1962, 1963; Fleischer and Price, 1964; Price et al., 1964]. In deeply eroded regions this retention is generally linked to cooling of the sample during progressive exhumation, and thus fission track (and other isotopic) ages provide a measure of rates of material exhumation [e.g., Sardarov, 1957; Hurley et al., 1962; Clark and Jager, 1969; Doherty and Lyons, 1980].

Brandon et al. [1998] derive broad patterns of exhumation across the Olympic Mountains and conclude that for the past 14 m.y. the Cascadia wedge has been in a flux steady state, defined as a balance between the accretionary flux of material into the wedge and the flux of material removed by erosion of the forearc high. However, the significance of their analysis, which accounted only for vertical transport of material through the wedge, is questionable because both the thermal structure of the 


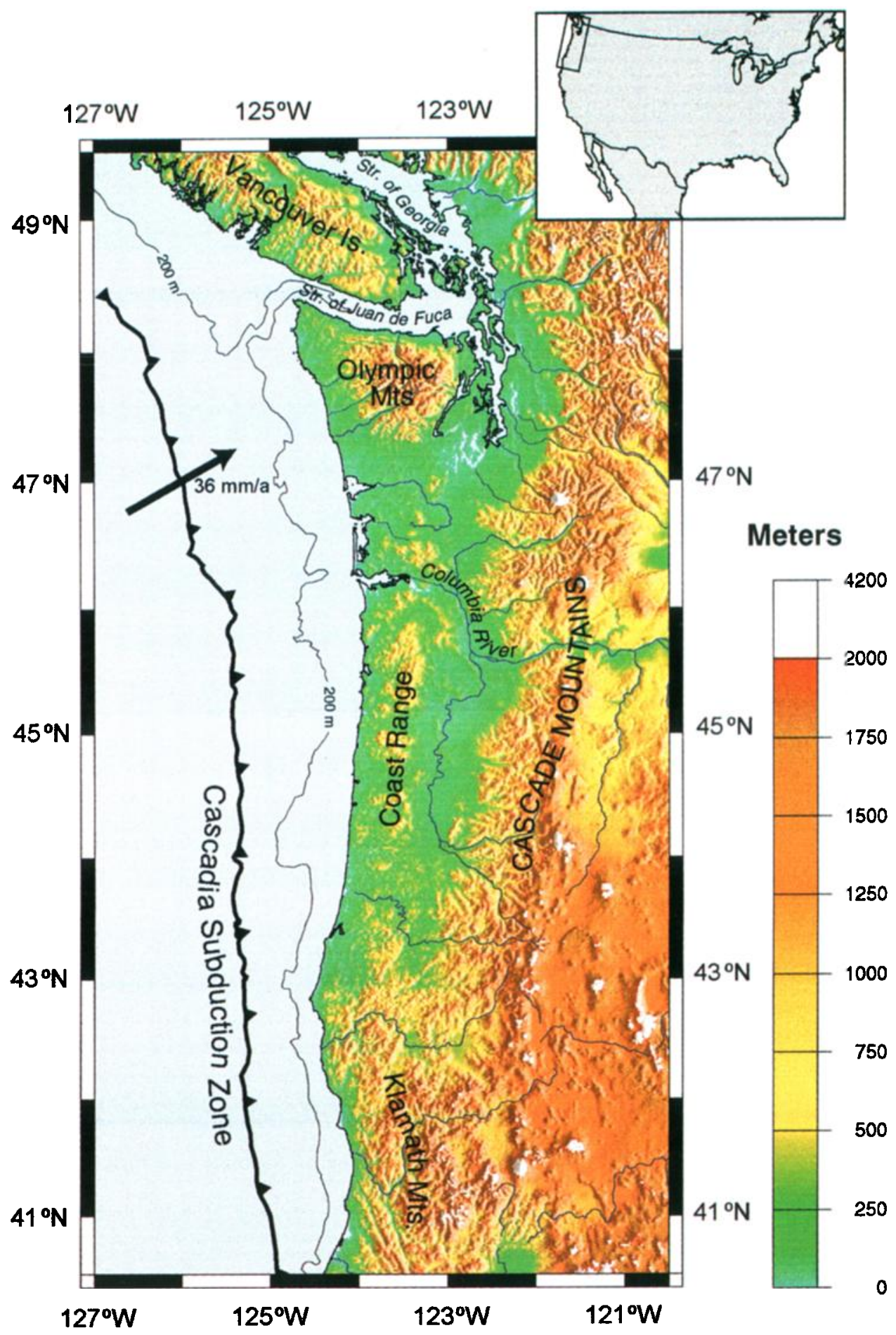

Plate 1. Key geographical features of the Cascadia margin. Indicated plate velocity (arrow) is for motion of the Juan de Fuca Plate relative to continental North America at the latitude of the Olympic Peninsula [DeMets et al., 1990; DeMets and Dixon, 1999]. 
Cascadia wedge [Lewis et al., 1988; Hyndman and Wang, 1993] and the uplift and exhumation rates experienced in the Olympic Mountains [Brandon et al., 1998, Pazzaglia and Brandon, 2001] vary across the margin. The overall material path of a rock through the Cascadia wedge and the thermal consequences of that path may thus be strongly influenced by any horizontal component of motion.

We build on the work of Brandon et al. [1998] by analyzing the tectonic significance of thermochronological data from the Olympic Mountains using a two-dimensional kinematic and thermal framework. The thermal evolution of the deforming wedge is modeled using a Lagrangian-Eulerian finite element method, which enables us to track the passage of selected material points through the model domain and to integrate their thermal histories. This modeling allows us to interpret thermochronological data in a context more consistent with the actual tectonic setting of the Cascadia wedge.

This approach is used to investigate two issues. First, what is the primary deformation mode driving uplift in the Olympics? The three options are (1) frontal accretion of the incoming sedimentary section of the Juan de Fuca Plate at the toe of the Cascadia wedge [e.g., Davis and Hyndman, 1989], (2) underplating of subducted material at depth beneath the orogen [e.g., Clowes et al., 1987; Brandon and Calderwood, 1990], and (3) margin-parallel deformation [e.g., Beck, 1991; McCaffrey and Goldfinger, 1995; McCaffrey, 1996; McCrory, 1996; Wang, 1996]. The second issue concerns the long-term evolution of the Cascadia margin. More specifically, has the Olympic segment been in a flux steady state during the Late Cenozoic [Brandon et $a l,, 1998]$ ? The model allows the thermochronological data to be used as a direct test of the steady state hypothesis.

\section{Regional Setting}

The continental framework inboard of the Cascadia forearc (Figure 1) was assembled in the late Cretaceous. The forearc region itself was subsequently built by the accretion of the Coast Range terrane and the more outboard Cascadia wedge. The Coast Range terrane (CRT) consists of a thick fault-bounded slab of lower Eocene oceanic crust and overlying marine clastic sediments informally known as the Peripheral sequence. This assemblage extends $750 \mathrm{~km}$ from southwest Oregon to the continental shelf west of Vancouver Island [Wells et al., 1984; Clowes et al., 1987] (Plate 1 and Figure 1). The origin of the ophiolitic basement of the CRT is ambiguous and may relate to collision of an intra-Pacific seamount province or to either back arc or forearc rifting at the North American margin [Wells et al., 1984; Clowes et al., 1987; Babcock et al., 1992]. The suture separating the basaltic CRT on its inboard side from the uplifted pre-Tertiary continental framework of North America is exposed only on southernmost Vancouver Island, where it is known as the Leech River Fault (Figure 1). Crosscutting relations broadly delimit suturing along this boundary to between 42 and $24 \mathrm{Ma}$ [Brandon and Vance, 1992]. Conglomerates shed southwestward from pre-Tertiary rocks north of the Leech River Fault on Vancouver Island indicate that the fault may have been active during the late Eocene. These conglomerates are exposed in the Lyre Formation within the Peripheral sequence on the north side of the Olympic Peninsula, and detrital zircon fission track ages reported by Garver and Brandon [1994] suggest that they have a depositional age of circa $38 \mathrm{Ma}$.
The modern configuration of the Cascadia margin, with hot young sediment-mantled oceanic lithosphere of the Juan de Fuca Plate being subducted west of the CRT, was considered by Brandon and Vance [1992] to have originated in latest Eocene time (circa $35 \mathrm{Ma}$ ). A late Eocene initiation is suggested by suturing of the CRT to the continental framework of North America between 42 and $24 \mathrm{Ma}$, as discussed above, initiation of the Cascade Volcanic Arc at circa $36 \mathrm{Ma}$ [Armstrong and Ward, 1991; Brandon and Vance, 1992], and the timing of slip on the Hurricane Ridge Fault in the Olympic Mountains [Brandon and Vance, 1992]. This interpretation contrasts with previous syntheses of the region that infer initiation of Cascadia subduction at circa $50 \mathrm{Ma}$ [e.g., Wells et al., 1984; Heller et al., 1987; Snaveley, 1987]. Plate reconstructions [Engebretson et al., 1985; Lonsdale, 1988; Wilson, 1988] and the volcanic record of the Cascade arc [Smith, 1989; Sherrod and Smith, 1989] suggest that after initiation of the Cascadia subduction zone, plate convergence proceeded in a fairly steady and.continuous fashion.

The Cascadia wedge formed outboard of the CRT and has grown by offscraping at the front of the wedge, and possibly underplating beneath the wedge as well [Clowes et al., 1987; Brandon and Calderwood, 1990]. Cascadia wedge sediments underlie most of the offshore continental margin [e.g., Clowes et al., 1987] but are only subaerially exposed in the Olympic Mountains. There, uplift and erosion have tilted the Peripheral sequence into a steep east plunging anticline (Figure 1), exposing the Cascadia wedge sediments underlying the Hurricane Ridge Fault in the interior of the massif [Stewart, 1970; Rau, 1973; Tabor and Cady, 1978a, 1978b] where they are known as the Olympic subduction complex (OSC) [Brandon and Vance, 1992] (Figure 1).

The anomalous uplift (Plate 1) and deep exhumation (Figure 1) of the Olympic Mountains are attributed by Brandon and Calderwood [1990] to the presence of a 10-km-high arch in the underlying Juan de Fuca Plate beneath the orogen. They argue that the low angle of slab dip beneath the Olympics resulted in a correspondingly early emergence of the region and rapid uplift of the Olympic massif, relative to adjacent regions of the subduction zone (see Pazzaglia and Brandon [2001] for further discussion of this interpretation). This effect may be further accentuated by the progressive northward increase in sediment flux rate along the Cascadia margin [e.g., Brandon et al., 1998] feeding the growth and deformation of the accretionary wedge.

As an alternative, regional scale plate motion and GPS data have been used to attribute the anomalous uplift of the Olympics to margin parallel motion, with the Olympic Peninsula supposedly caught between the northward moving Oregon Coast Range block and the relatively stable "buttress" of Vancouver Island and uplifted rapidly as a result [e.g., Wells et al., 1984; McCaffrey and Goldfinger, 1995; McCaffrey, 1996; McCrory, 1996; Wang, 1996]. Pazzaglia and Brandon [2001] refute major margin-parallel deformation by using deformed erosional benchmarks to estimate long-term permanent strain rates across the Olympics. Pazzaglia and Brandon [2001] argue that longterm permanent shortening is mainly occurring across the orogen, parallel to the Juan de Fuca-North America convergence direction at a rate of $3 \mathrm{~km} \mathrm{Myr}^{-1}$ over a $140 \mathrm{~km}$ baseline. At the core of this argument is the observation that rates of rock uplift and erosion across the Olympic Mountains appear to be in close agreement with the accretionary flux associated with convergence. Orogen-parallel shortening would increase 


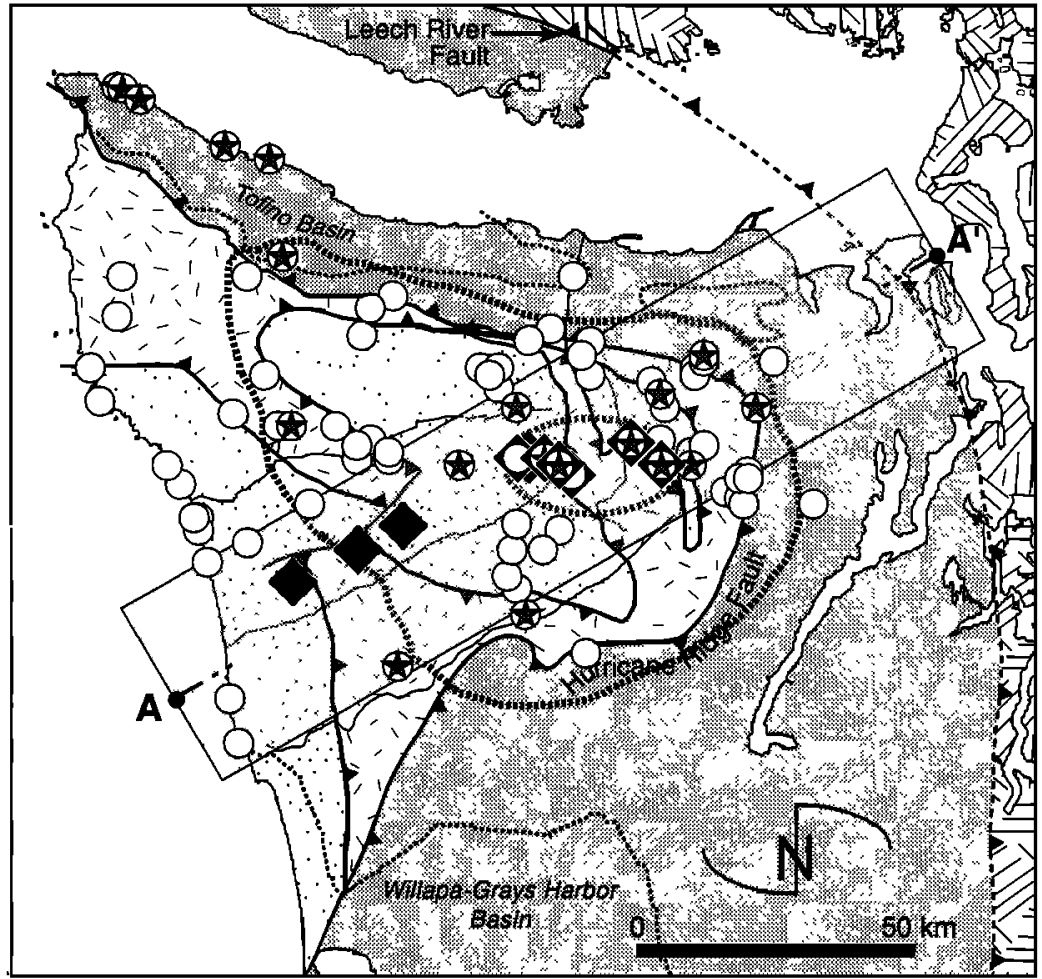

Geology Legend

Coast Range Terrane: Crescent basalt and Peripheral sequence

-iv Continental interior

Major basins of the

Peripheral sequence

Olympic Subduction Complex

Lower OSC and Coastal OSC

Upper OSC

\section{Data Legend}

Apatite fission track age

$\star$ Zircon fission track age

- Apatite (U-Th)/He age

Base of PAZs for

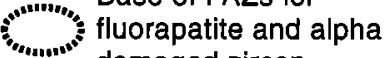
damaged zircon

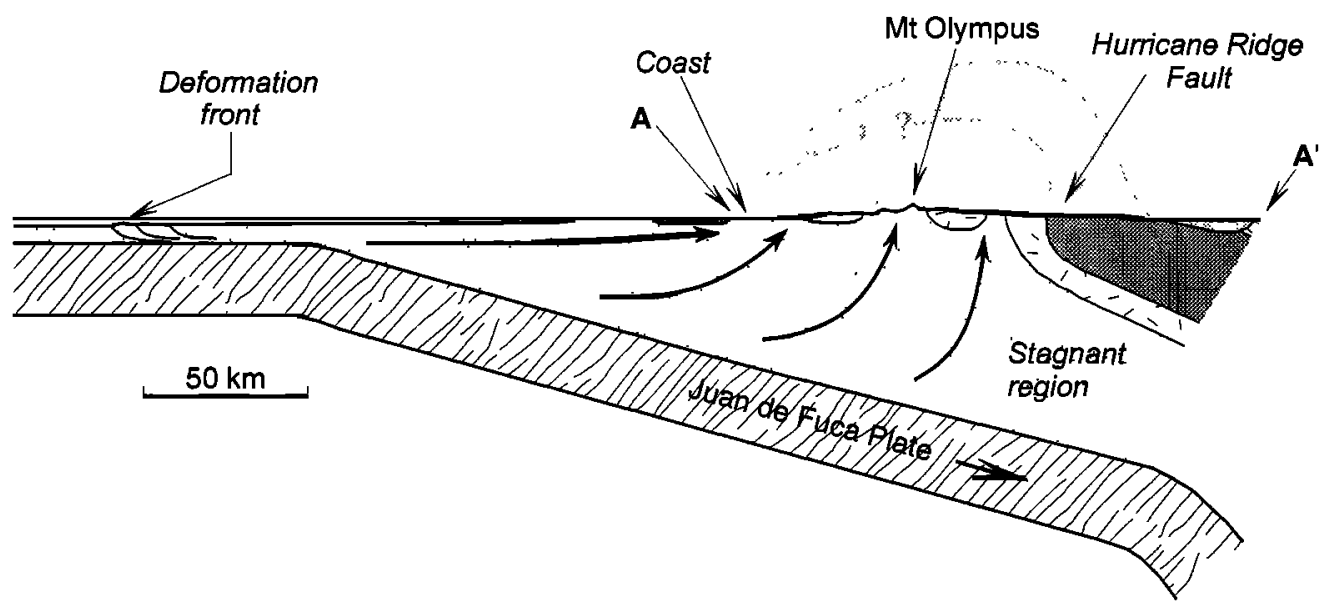

Figure 1. Geology and thermochronological sample coverage of the Olympic Peninsula after Brandon et al. [1998]. Note the locations of the new (U-Th)/He data reported in this paper. Section A-A' parallels convergence of the Juan de Fuca Plate relative to continental North America and passes through the region of deepest exhumation in the Olympic Mountains. The box centered about A-A' marks the limit of samples projected into the section line for this study, as discussed in text. Also shown is a figurative cross section illustrating the key structural and tectonic nature of the Olympic section of the Cascadia wedge [after Brandon et al., 1998].

accretionary flux above this level, which runs against other evidence that the Olympic Mountains segment of the Cascadia wedge has maintained a steady-state size for the last $14 \mathrm{Myr}$ [Brandon et al., 1998; Pazzaglia and Brandon, 2001]. Our modeling here provides a test of the steady-state hypothesis, and thus has a bearing on this debate over the relative importance of orogen-parallel versus orogen-normal shortening in the Olympics.

\section{Modeling}

We aim to resolve two questions here: (1) What is the basic accretionary mode of the Olympics? (2) Has the distribution of erosion rates across the orogen varied on the million-year timescale constrained by the available thermochronological data? We begin below by describing an approach for modeling the coupled physical and thermal evolution of an eroding accretionary wedge. This coupling of physical and thermal behavior allows us to use thermochronology as a direct constraint on orogenic development. The model calculates ages by taking selected material points at the surface at the nominal "presentday" and back tracking their passage to their points of entry into the wedge. Exhumational and thermal histories are then compiled using points along the calculated material paths and compared to the thermal response of different thermochronometers (the zircon fission track, apatite fission track, and apatite (U-Th)/He dating 
Table 1. Model Parameters

\begin{tabular}{lll}
\hline \multicolumn{1}{c}{ Parameter } & Value & \multicolumn{1}{c}{ Reference } \\
\hline Time step length $\Delta t, \mathrm{kyr}$ & 36 & \\
Crustal thermal conductivity $\kappa_{c}, \mathrm{~W} \mathrm{~m}^{-1} \mathrm{~K}^{-1}$ & 2.0 & Brandon and Vance [1992] \\
Mantle thermal conductivity $\kappa_{m}, \mathrm{~W} \mathrm{~m}^{-1} \mathrm{~K}^{-1}$ & 2.9 & Hyndman and Wang [1993] \\
Crustal heat capacity $C_{p}, \mathrm{~J} \mathrm{~kg}^{-1} \mathrm{~K}^{-1}$ & 1200 & Dumutru [1991] \\
Heat production $H, \mu \mathrm{W} \mathrm{m}^{-3}$ & 0.6 & Lewis et al. [1988] \\
Mantle density $\rho_{m}, \mathrm{~kg} \mathrm{~m}^{-3}$ & 3700 & \\
Crustal density $\rho_{c}, \mathrm{~kg} \mathrm{~m}^{-3}$ & 2900 & \\
\hline
\end{tabular}

systems) to predict the patterns of ages that we would observe at the surface for given orogenic scenarios

As with previous thermal modeling of the Cascadia margin [e.g., Moran and Lister, 1987; Lewis et al., 1988; Hyndman and Wang, 1993], we assume that heat flow occurs primarily by conduction, with advection of heat by moving fluids playing a negligible role. This simplification is probably appropriate, as we are interested primarily in the rear of the wedge, well removed from any influence that rapid dewatering during accretion might have on the thermal structure of the wedge [Davis et al., 1990; Hyndman et al., 1993; Wang et al., 1993]. In the absence of fluid transport, the time-dependent temperature field in a deforming medium, such as the active accretionary wedge, is described by [Carslaw and Jaeger, 1959]

$$
\frac{\partial T}{\partial t}+u \cdot \nabla T=\kappa \nabla^{2} T+\frac{H}{C},
$$

where $\boldsymbol{u}$ is material velocity, $T$ is temperature, $t$ is time, $\kappa$ is the thermal diffusivity of the medium, $C$ is the heat capacity of the medium, and $H$ is the internal heat production per unit volume (Table 1).

Thermal conductivity for the Olympic subduction complex is estimated to be $2.0 \mathrm{~W} \mathrm{~m}^{-1} \mathrm{~K}^{-1}$ [Brandon and Vance, 1992]. This value is derived as a weighted harmonic mean of compiled thermal conductivity data from Oxburgh [1980] and Oxburgh and Wilson [1989], assuming an average vertical section through the wedge consisting of $50 \%$ Coast Range basalt and $25 \%$ sandstone and $25 \%$ mudstone in the underlying OSC. Internal heat production is taken as $0.6 \mu \mathrm{W} \mathrm{m} \mathrm{m}^{-3}$ of solid rock, as measured in shelf sediments from offshore wells on the Vancouver Island Margin [Lewis et al., 1988]. The underlying slab of oceanic crust is assumed to have a negligible heat production because of low concentration of radioactive isotopes.

Although frictional heating can also be included as a

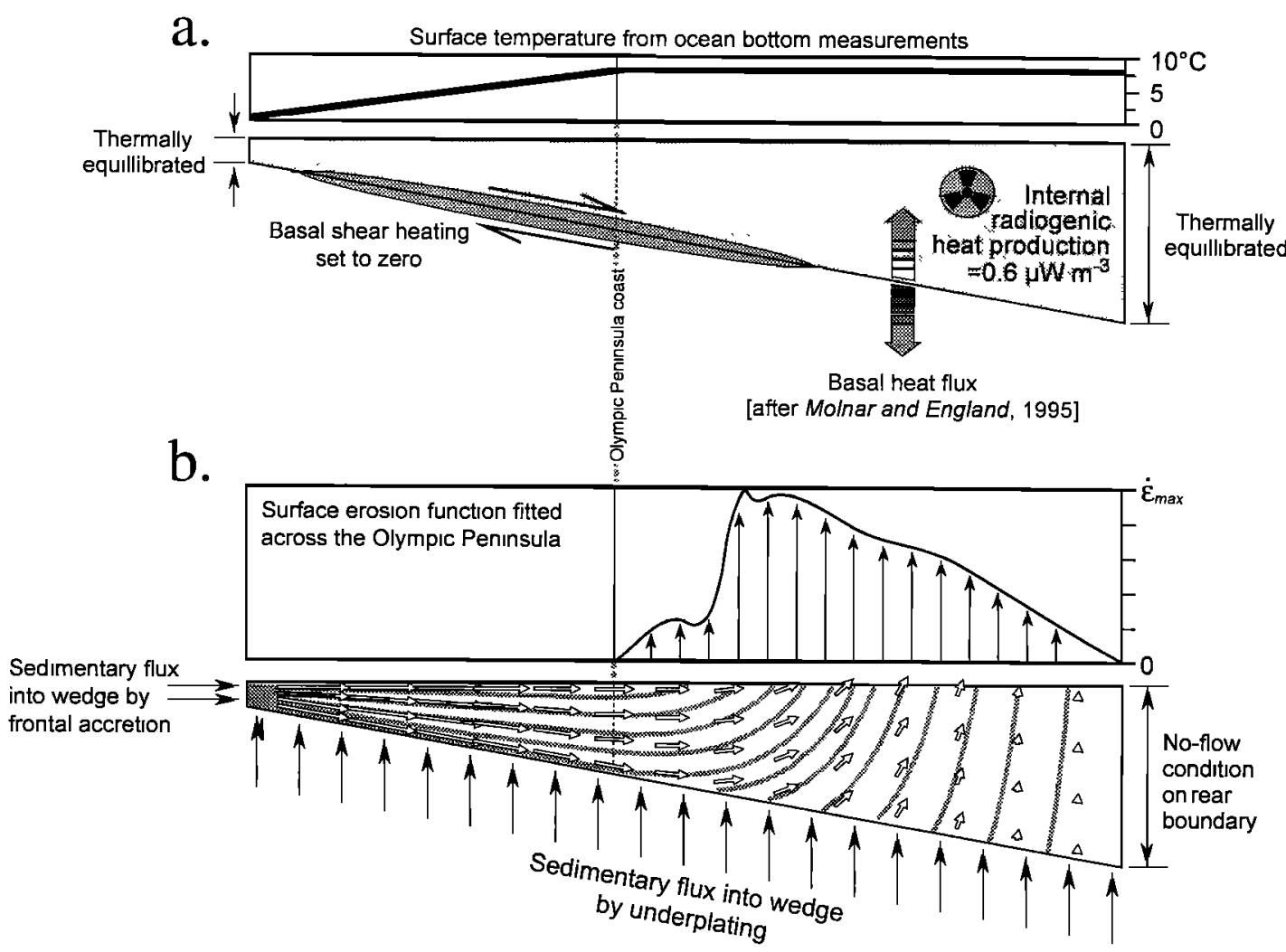

Figure 2. Boundary conditions and key features of the numerical model described in the text. (a) Thermal model conditions. (b) Kinematic model conditions. The form of the surface erosion function is taken from Pazzaglia and Brandon [2001], but the magnitude of the function $\left(\dot{\varepsilon}_{\max }\right)$ is a free parameter in the model. 
contribution to $H$ in this calculation (Equation 1), this parameter is set to zero in the final models presented below. In their analysis, Hyndman and Wang [1993] concluded that surface heat flow data did not support friction as a significant heat source for the Cascadia wedge. Our modeling similarly suggests that frictional heating must be very low in order to account for the observed thermochronological data of the Olympics. Low frictional heating is further supported by the multichannel seismic observations of Fisher et al. [1999] offshore of Washington State and other regional observations [e.g., Hyndman and Wang, 1995; MacKay, 1995; Wang et al., 1995], which suggest only weak coupling at the basal décollement.

In the model, the wedge surface is maintained at a fixed temperature (Figure 2a). Onshore, the mean annual surface temperature of the Olympics of $8^{\circ} \mathrm{C}$ is [Brandon and Vance, 1992], while offshore, oceanographic and ocean bottom thermal probe measurements suggest surface temperature decreases progressively seaward, reaching $\sim 0^{\circ} \mathrm{C}$ at the deformation front of the accretionary wedge [Davis et al., 1990]. The left and right boundaries of the wedge are assumed to have no net heat-flux across them.

The basal boundary temperature of the wedge is set according to the method of Molnar and England [1995], which provides an analytical approximation for temperature at the base of an accretionary wedge as a function of the rate and geometry of slab subduction, and the age of the slab. Because of the young age of the Juan de Fuca Plate, which is only $8 \mathrm{Ma}$ at the Cascadia subduction zone offshore of the Olympics [Moran and Lister, 1987], the contribution of heat from the downgoing oceanic slab is considerable. Surface heat flux levels at the Cascadia subduction zone approach $70 \mathrm{~mW} \mathrm{~m}$, with temperatures at the top of the basaltic oceanic crust beneath the accumulated sedimentary blanket estimated to be as high as $200^{\circ} \mathrm{C}$ [e.g., Yorath et al., 1985; Lewis et al., 1988].

Internal motions within the wedge play an important role in the cooling history of a sample [Jamieson et al., 1996; Batt and Braun, 1997]. To interpret the significance of isotopic ages, we must consider both the thermal structure of the wedge and the path taken by the sample during its passage through that thermal structure. We use a simple kinematic model from Pazzaglia and Brandon [2001] to represent the key features of the velocity field in the wedge.

Our null hypothesis is that the wedge is in a flux steady state throughout the model run time (Figure 3 ). The entire sedimentary section of the subducting Juan de Fuca Plate is assumed to be incorporated into the Cascadia wedge, either by accretion at the toe or underplating beneath the deforming wedge (Figures $2 b$ and
3). This displacement field is assumed to be two-dimensional (plane strain) and oriented parallel to the Juan de Fuca-North America convergence direction. Motion of material perpendicular to this section is not explicitly included in the model but is addressed instead in terms of its additional contribution to the material budget of the deforming wedge, as any such orogen parallel deformation would prevent balance being attained between accretionary influx and erosional outflux in our models.

The compaction of sediment is assumed to occur instantaneously during the initial stage of subduction, so that material within the wedge is effectively incompressible [e.g., Dahlen and Suppe, 1988]. We consider two competing mechanisms for the accretion of sedimentary material into the wedge. The first is underplating, where sediments are carried beneath the wedge together with the underthrust oceanic plate and then decoupled from the subducting slab and incorporated into the wedge at depth beneath the orogen. The second alternative is frontal accretion, where material is scraped off the oceanic crust at the point of subduction and incorporated into the toe of the wedge. The underplating and frontal accretion solutions provide end-members of behavior where vertical or horizontal velocities, respectively, are maximized. It is important to consider this range of velocity fields because of the highly twodimensional (2-D) (and perhaps three-dimensional) setting of the Cascadia wedge. At the latitude of the Olympics the Juan de Fuca Plate is converging with stable North America at a rate of $36 \mathrm{~mm}$ $\mathrm{yr}^{-1}$ oriented at $054^{\circ}$, nearly orthogonal to the modern subduction zone (option 2 for Juan de Fuca/Pacific of DeMets et al. [1990], and "NA-PA combined" of DeMets and Dixon [1999] (Plate 1).

The frontally accreted influx of material at the toe of the wedge is given by

$$
\Omega_{f}=\alpha(1-\bar{n}) h_{0} V_{\mathrm{c}}
$$

where $h_{0}$ and $\bar{n}$ are the thickness (2 km [after Kulm et al., 1984]) and average porosity (27\% [from Yuan et al., 1994] of the incoming sedimentary section, respectively, $V_{\mathrm{c}}$ is the orthogonal convergence velocity ( $36 \mathrm{~mm} \mathrm{yr}^{-1}$, as discussed above), and $\alpha$ is the fraction of the sedimentary section accreted at the toe of the wedge.

The remainder of the sedimentary material is assumed to be underplated. In the absence of lateral motion, underplating would be expected to lead to the compensatory uplift of the overlying column of rock. Adopting this kinematic simplification, we distribute the underplating flux in direct proportion to the surface uplift velocity across the Olympics. This construction is useful because it is similar to the 1-D thermal analysis used by Brandon

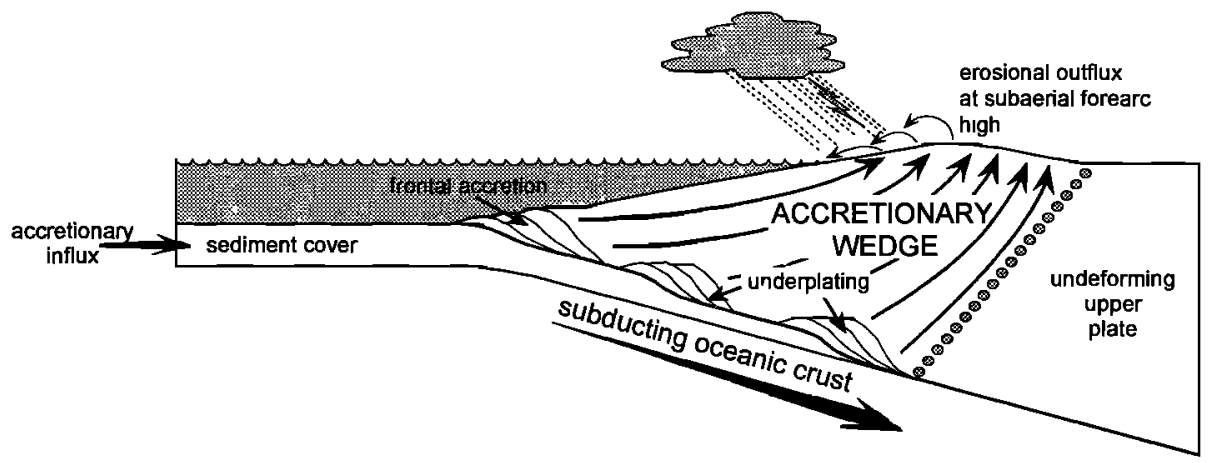

Figure 3. Figurative cross section illustrating the accretionary wedge behavior assumed in the model. 
et al. [1998], where horizontal velocities were considered insignificant. The influx of underplated material is described by

$$
\Omega_{u}=\int_{0}^{w} f_{u}(x) d x=(1-\alpha)(1-\bar{n}) h_{0} V_{\mathrm{c}},
$$

where $f_{u}(x)=(1-\alpha) \dot{\varepsilon}(x) d x$ is the specific underplating flux at a distance $x$ landward of the deformation front, $\dot{\varepsilon}(x)$ is the erosion rate at the surface immediately above $x$, and $W$ is the width of the actively deforming wedge.

In the absence of a specific dynamic model, we make the simplifying assumption that $\partial u / \partial z=0$, where $u$ is horizontal velocity and $z$ is the vertical dimension. This assumption is similar to the use of an average horizontal velocity for 2-D sheet thin-skinned tectonic modeling [e.g., Holt, 1989; Devoe et al., 1992]. Horizontal velocity is determined by maintenance of a flux balance,

$$
u(x, z)=u(x, 0)=\alpha \frac{\left(h_{0} V_{c}-\int_{0}^{x} \dot{\varepsilon}(x) d x\right)}{h(x)},
$$

where $h(x)$ is the thickness of the wedge at a distance $x$ from the deformation front. The vertical velocity $w$ can then be obtained from the continuity equation $\partial u / \partial x+\partial w / \partial z=0$, such that we can differentiate (4) to obtain

$$
w(x, z)=w(x, 0)-\frac{z \dot{\varepsilon}(x)}{h(x)}-\frac{z \tan \phi}{h^{2}(x)} \int_{0}^{x} \dot{\varepsilon}(x) d x .
$$

The flux steady-state condition specifies that vertical velocity at the surface $w(x, 0)$ is everywhere equal and opposite to the erosion rate $\dot{\varepsilon}(x)$. The transition to the stable North American plate at the rear of the wedge occurs where a balance is attained between accretionary and erosional fluxes, such that $u$ and $w$ equal zero.

The model assumes a rock uplift and erosion function of the form defined for recent Olympic Mountains uplift by Pazzaglia and Brandon [2001], but with its amplitude as a free parameter. The Pazzaglia and Brandon [2001] uplift function is mainly derived from fluvial incision rates over the last $140 \mathrm{kyr}$ in the western Olympics, together with evidence that the east and west coasts of the Peninsula have seen little long-term Neogene uplift and erosion. Pazzaglia and Brandon [2001] also showed that the pattern in the western Olympics was similar to that indicated by long-term (3-7 Ma) exhumation rates derived from apatite fission track ages. If it holds true across the entire peninsula, this correspondence allows estimation of the rates of uplift and erosion across almost the entire Olympic orogen.

Calculated erosion rates rise rapidly from zero at the west coast of the Olympic Peninsula, reach a peak in the west of the Olympic Mountains, and then decrease progressively to the east (Figure 2b). This asymmetric form may be a result of orographic rainfall focussed on the western, seaward side of the peninsula [Pazzaglia and Brandon, 2001]. Our modeling here will allow us to test more closely how the thermochronological data fit the short-term geomorphic indicators of uplift presented by Pazzaglia and Brandon [2001].

As noted previously, the first step in calculating model isotopic ages is to select material points at the surface of the model at the nominal present day and to track their path back to their entry into the wedge. The exhumational and thermal histories of these points are then compiled using model results from different time steps corresponding to the calculated material paths.
Apatite fission track ages are predicted by modeling the annealing of fission tracks as a function of time and temperature. This model is based on the experimentally derived annealing response of fission tracks in fluorapatite, as evaluated by Willett [1997]. The results of Willett's model closely match those of other popular annealing models [e.g., Duddy et al., 1988; Crowley, 1993].

The thermal history of each selected point is divided into a number of time steps $m$, each of length $\Delta t_{l}$. At each time step, a new set of tracks are assumed to form according to the ${ }^{238} U$ decay rate. The apatite fission track annealing response [Willett, 1997] is then integrated over the remainder of the modeled thermal history, thereby giving the predicted track length distribution. The final fission track age of the sample is calculated as a sum of the relative contributions of the tracks created at each time step, weighted for track length and observational bias [Laslett et al., 1987; Green, 1988; Willett, 1997].

This method is not applied to zircon fission track ages here because of the lack of an accepted track length model for the annealing of fission tracks in zircon over geological timescales. Laboratory annealing studies [e.g., Tagami et al., 1990; Yamada et al., 1995] suggest a closure temperature for the zircon fission track system some 50 to $100^{\circ} \mathrm{C}$ higher than that derived from studies of the geological record [e.g., Zaun and Wagner, 1985; Brandon and Vance, 1992; Foster et al., 1996]. Following Kasuya and Naeser [1988], Brandon and Vance [1992] and Brandon et al. [1998] argue that this discrepancy is due to the influence of accumulated $\alpha$ damage (lattice damage due to the decay of $U$ and Th by $\alpha$ particle emission) on the thermal stability of fission tracks in zircon.

In light of this issue, we instead utilize effective closure temperatures, calculated from the relationship [Dodson, 1979]

$$
\dot{T}=\frac{-R T_{c}{ }^{2}}{\bar{E} B \mathrm{e}^{\bar{E} / R T_{c}}}
$$

where $R$ is the gas constant, $\bar{E}$ is the "average" activation energy

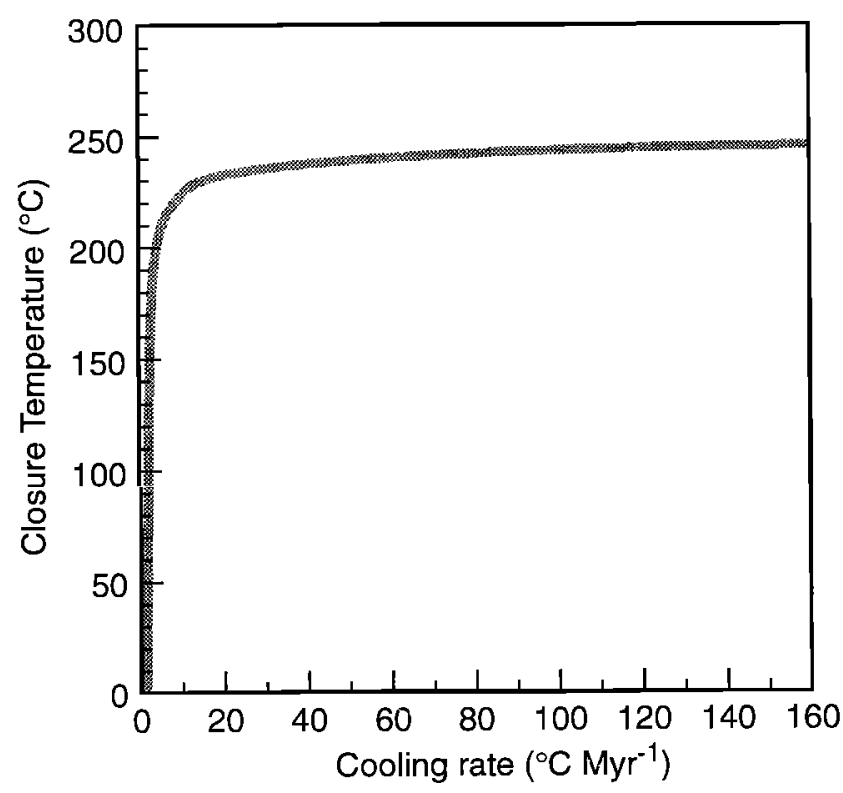

Figure 4. Variation of zircon fission track closure temperature with cooling rate. Derived from (6) assuming $\bar{E}=49.77 \mathrm{kcal}$ $\mathrm{mol}^{-1}$, and for $B=3.160 \times 10^{-22} \mathrm{Myr}$. 
(as evaluated at $50 \%$ annealing), $B$ is a materially dependent proportionality constant, and $\dot{T}$ and $T_{c}$ are the cooling rate and effective closure temperature, respectively. Brandon and Vance [1992] and Brandon et al. [1998] estimate the constants in (6) from the annealing data of Zaun and Wagner [1985] and Tagami et al. [1990], arriving at values of $49.77 \mathrm{kcal} \mathrm{mol}^{-1}$ for $\bar{E}$ and $3.160 \times 10^{-22} \mathrm{Myr}$ for $B$. These values yield the relationship shown in Figure 4. Zircon fission track ages in the model are calculated by determining the time at which temperature falls below $T_{c}$ for the relevant cooling rate $\dot{T}$. This calculation requires iterative solution of (6) because the equation cannot be recast to give an analytical solution for time. The effective closure temperatures predicted by this model (Figure 4) are consistent with the study of Foster et al. [1996], which used timetemperature histories determined by ${ }^{40} \mathrm{Ar}-{ }^{39} \mathrm{Ar}$ analysis of potassium feldspar to estimate closure temperatures for associated zircon fission track ages as a function of cooling rate.

Apatite (U-Th)/He ages are calculated directly by modeling the production and diffusion of helium in apatite as a function of time and temperature, after the approach described by Wolf et al. [1996]. Assuming uniform distribution of uranium and thorium within the sample, the change in ${ }^{4} \mathrm{He}$ concentration over a time step is given by numerically solving for the balance of diffusion and production of ${ }^{4} \mathrm{He}$ over the duration of the step $t$, as a function of radial position $r$ within a spherical diffusion domain of radius $a$. The governing equation is

$$
\frac{\partial C}{\partial t}=\frac{D(t)}{a^{2}}\left[\frac{\partial^{2} C}{\partial r^{2}}+\frac{2}{r} \frac{\partial C}{\partial r}\right]+\int_{0}^{t} P(t) d t,
$$

where $a$ is the characteristic diffusion dimension of the system, $C$ is the concentration of ${ }^{4} \mathrm{He}$, and $P(t)$ is the production rate of ${ }^{4} \mathrm{He}$. $D(t)$ is the temperature-dependent diffusion coefficient given by

$$
D(t)=D_{0} \mathrm{e}^{-E / R T(t)}
$$

where $D_{0}$ is the diffusion coefficient at infinite temperature, $R$ is the gas constant, $T(t)$ is the absolute temperature of the sample at time $t$, and $E$ is the activation energy of the system. Following the experimental work of Farley [2000] on Durango apatite, we adopt helium diffusion characteristics of $E=33 \pm 0.5 \mathrm{kcal} \mathrm{mol}^{-1}$ and $\log \left(D_{0}\right)=1.5 \pm 0.6 \mathrm{~cm}^{2} \mathrm{~s}^{-2}$ for apatite. The characteristic diffusion dimension $a$ is believed to be the radius of the apatite grain [Farley, 2000]. For our model, this is taken to be $50 \mu \mathrm{m}$, approximately corresponding to the average radius of the grains analyzed in this study (Table 2).

\section{Thermal and Thermochronological Data}

The Olympic Peninsula is covered by a dense set of zircon and apatite fission-track ages from Brandon and Vance [1992] and Brandon et al. [1998] (Figures 1 and 5). Fission track samples are characterized as either reset or unreset. Unreset samples generally display discordant grain ages older than the deposition age of the sedminents, reflecting the heterogeneous cooling histories of their sedimentary provenance regions. As these ages are inherited by the detrital material, they offer no direct constraint on the recent thermal history of the region. Samples are considered to be reset when (1) the observed age falls below the deposition age of the sample and (2) the wide age variation typical of an unreset sample is replaced by a narrow range of grain ages [Brandon and

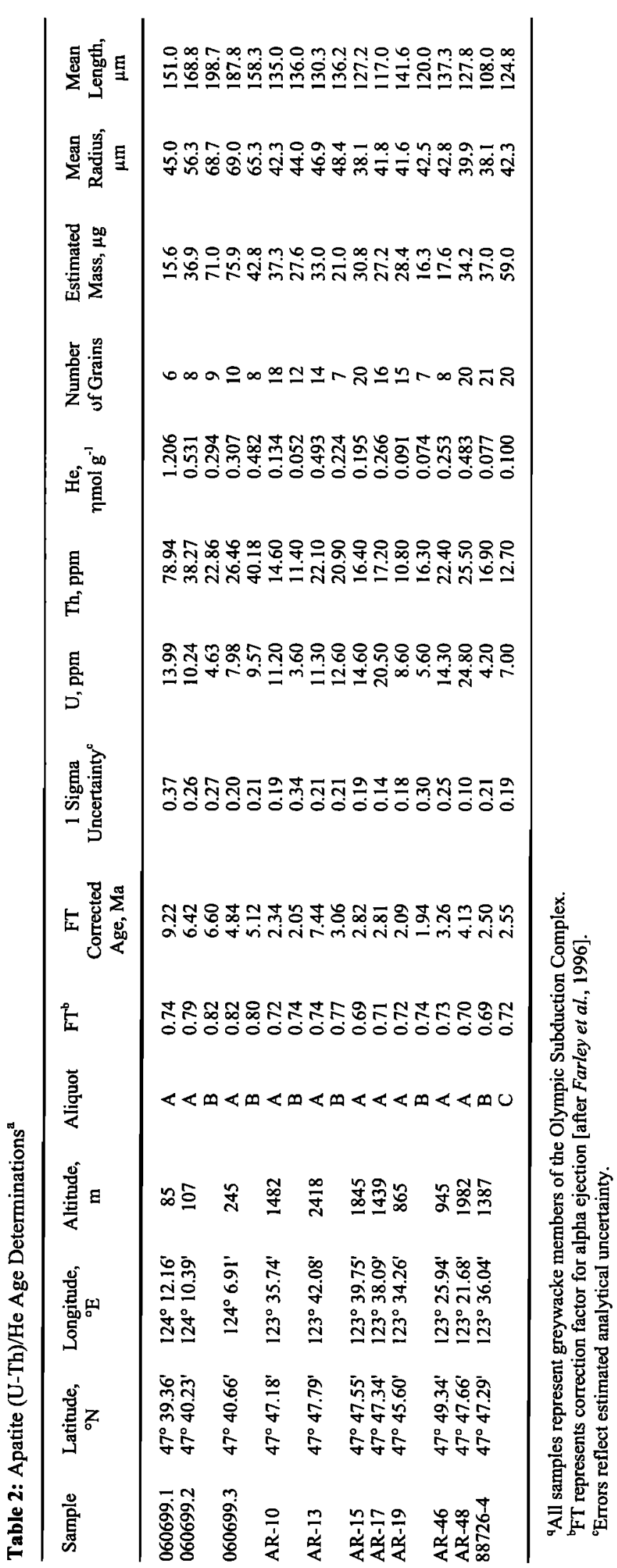




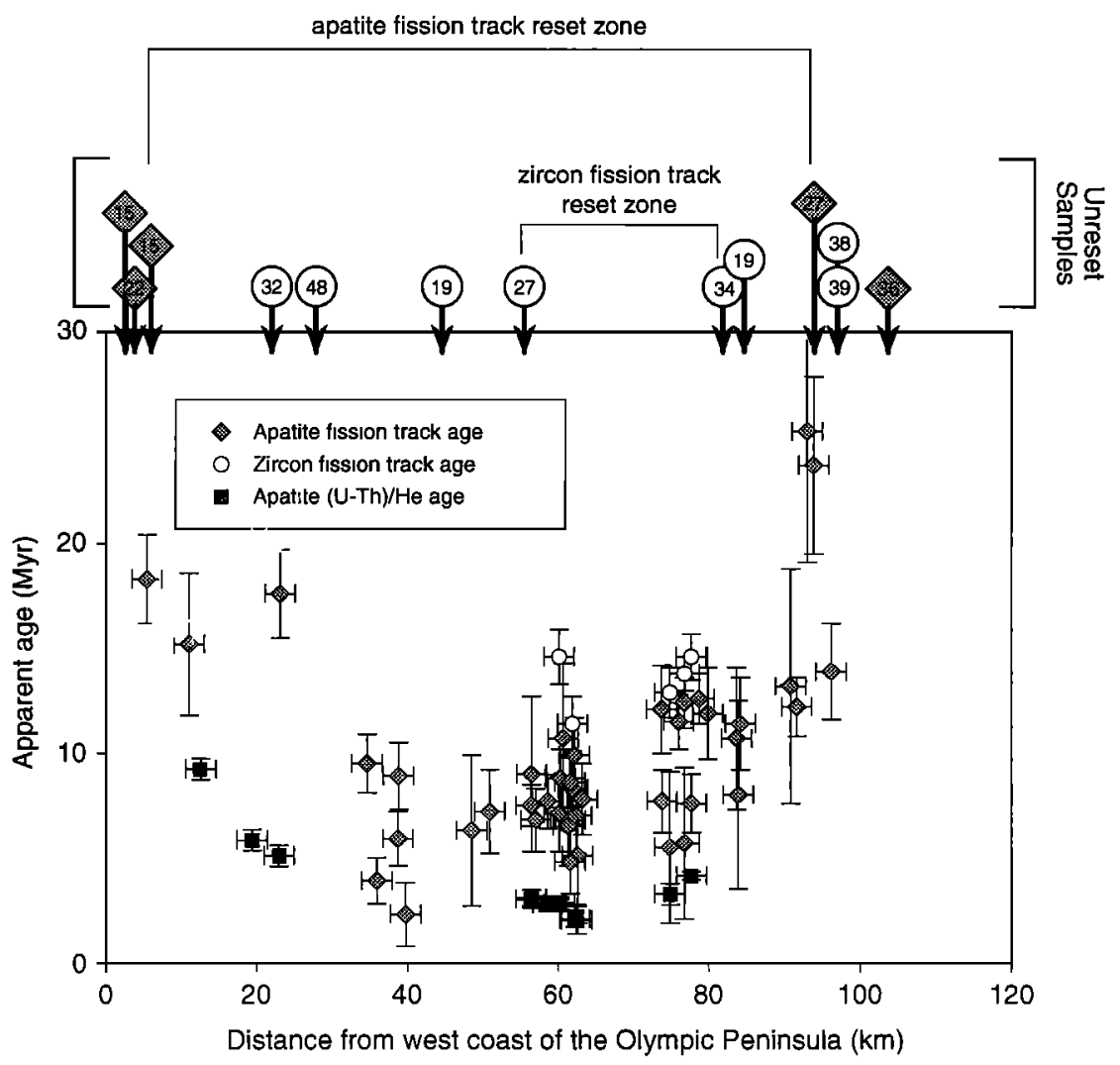

Figure 5. Thermochronological data used to constrain the model, plotted as apparent age versus distance along section A-A' (Figure 1). Error bars indicate $1 \sigma$ uncertainty for age and an assumed $\pm 2 \mathrm{~km}$ variability in relative position to account for the projection of geographically distributed points onto a single section line. Unreset ages are identified by the population characteristics of individual samples (as discussed in the text) and are marked as individual ages along the top boundary. These reset ages are inherited from their sedimentary source and are not reflective of the recent deformation and exhumation of the Olympic subduction complex. Zircon fission track ages come from Brandon and Vance [1992] and Garver and Brandon [1994], apatite fission track ages from Brandon et al. [1998], and (U-Th)/He ages are presented in this study in Table 2.

Vance, 1992; Brandon et al., 1998]. These changes reflect the erasure of the earlier thermal history of the samples during burial and heating, with the reset age indicating the subsequent cooling undergone by the sample during its exhumation.

Due to the presence of mixed grain populations of varying character in the sediments of the OSC, Brandon et al. [1998] use the binomial peak fit method of Galbraith [1988] and Galbraith and Green [1990] to isolate a minimum age for each sample. For unreset samples the minimum age represents the age of the youngest component of detrital grain ages. For reset samples the minimum age corresponds to the cooling age for the fraction of grains that were last to close (i.e., closed at the lowest temperature). For apatite, that fraction typically consists of the most fluorine-rich grains in the sample. For zircon the youngest cooling ages appear to correspond to the grains that had the largest amount of accumulated $\alpha$ damage prior to thermal resetting of the sample

Brandon et al. [1998] delineate a discrete zone of reset zircon fission track ages exposed in the center of the Olympic Mountains (Figure 5). The metamorphic grade and degree of ductile deformation support the conclusion that this region is the most deeply exhumed part of the Olympics [e.g., Tabor and Cady, 1978a; 1978b; Brandon et al., 1998]. For our analyses here, we group together ages along a transect parallel to the direction of plate convergence across the Olympic Peninsula, centered on this reset zircon zone and wide enough to encompass it (see area outlined around section line A-A' in Figure 1). This grouping includes a total of 50 apatite fission track samples covering a total of $100 \mathrm{~km}$ of the $\sim 120 \mathrm{~km}$ width of the Olympic Peninsula at this point, and 13 zircon fission track samples covering $75 \mathrm{~km}$ of the peninsula (Fig. 6). Sample density along this transect is sufficient to constrain the boundaries between unreset and reset apatite fission track ages to within $\sim \pm 2 \mathrm{~km}$ (Figure 5). For zircon fission track ages the eastern boundary of the reset zone is similarly well constrained to $\sim \pm 2 \mathrm{~km}$, while less dense sample coverage limits resolution of the western boundary of the reset zone to $\sim 4 \mathrm{~km}$ (Figure 5).

Apatite and zircon fission track ages display the same broad patterns of variation across the Olympics. For both chronometers, ages are reset and youngest (5-6 Ma for apatite, $13 \mathrm{Ma}$ for zircon) in the more deeply exhumed interior of the orogen, increase markedly toward both east and west, and undergo a transition to unreset ages toward the botindaries of the Olympic Peninsula (Figure 5). Notably, the age minima of the zircon and apatite fission track chronometers are offset from one another by some $20 \mathrm{~km}$ (Figure 5).

Eleven new apatite (U-Th)/He ages from the Olympic subduction complex (OSC) are presented here (Figure 5 and 


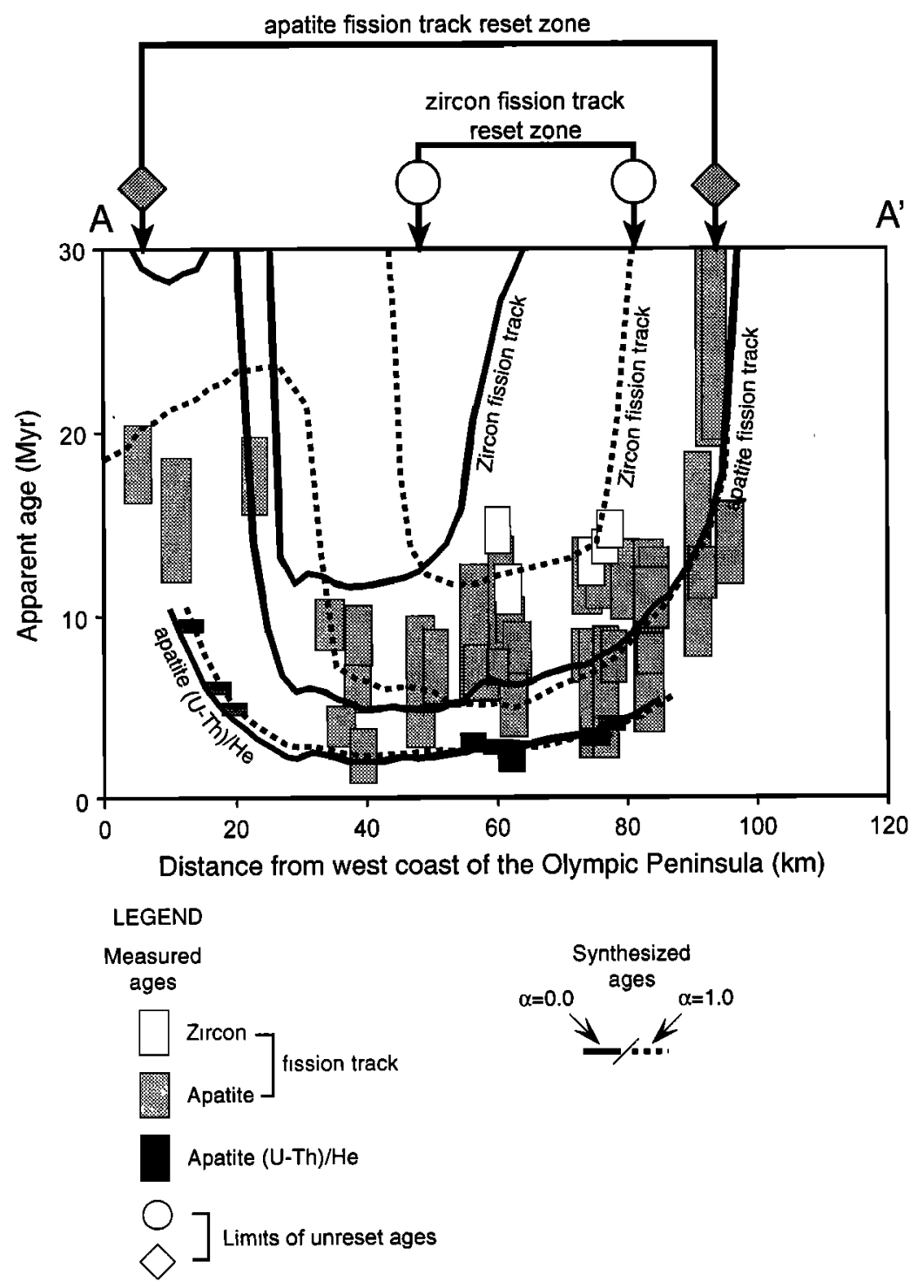

Figure 6. Explicit model fit to thermochronological data with varying $\alpha$. All model age distributions shown here assume $\dot{\varepsilon}_{\max }=0.95 \mathrm{~mm} \mathrm{yr}^{-1}$. Data are shown as boxes reflecting relative uncertainty on age and position along $\mathrm{A}-\mathrm{A}^{\prime}$ (Figure 5). For clarity, only the innermost unreset age locations are indicated, illustrating the maximum possible size of the reset age zones for different chronometers. Distal limits of the modeled apatite (U-Th)/He age profiles are omitted for clarity where age constraint is lacking.

Table 2), spanning a geographic range of $60 \mathrm{~km}$, or half the width of the Olympic Peninsula (Figure 5). These samples comprise partially volcanigenic graywackes, with mixed apatite morphologies ranging from euhedral and prismatic to rounded and abraded. The most euhedral grains possible were picked from each sample and were analyzed using the techniques outlined by House et al. [1997]. The reported errors represent the estimated analytical precision of the analyses to one standard deviation [Wolf et al., 1996]. Analysis AR-13(a) is rejected from analysis as both anomalously old and unreproducible, possibly due to the presence of small undetected inclusions of other $\mathrm{U}$ - and Thbearing phases in the apatite sample. All other replicated analyses agree to within estimated uncertainties on sample age (Table 2).

Eight samples from the central core of the Olympic Mountains (Figures 1 and 5) display relatively consistent ages of 2 to $3 \mathrm{Ma}$, and although not sampled to define a specific topographic profile, their ages are broadly correlated with elevation (Table 2 ). When the more peripheral samples from the Clearwater River are included, a general increase in age can be observed from the core of the orogen toward its western margin, as observed in the higher-temperature fission track systems (Figure 5).

\section{Model Results}

The model provides three general observables that vary with the interaction of the kinematic and thermal conditions of the wedge. The most important of these are the synthetic age profiles developed for each of the three modeled chronometers (apatite and zircon fission track ages and apatite (U-Th)/He ages). Where the exhumation path leading to a surface point is such that material cooled through the relevant closure temperature during the model run, the observed ages are indicators of model kinematics. Such "reset" ages reflect the time between thermochronological closure at depth in the wedge and exposure 
at the surface and hence are functions of the path-averaged exhumation rate. As seen in Figure 6, this gives low ages in the central part of the orogen where erosion rates are high, with ages increasing toward the margins of the wedge as erosion rates fall to zero. The exact distribution of ages depends on $\alpha$, which controls the horizontal component of the velocity field.

The second observable is the distribution of reset ages along the section. Over time as the total accumulated exhumation increases, the lateral extent of the domain of reset ages expands to include areas of lower mean erosion rate. If material at a given point is being exhumed from deeper in the wedge than the relevant closure temperature, a reset age will eventually be exposed at that location by progressive exhumation. If exhumation paths leading to a point are so shallow that they do not sample below the relevant closure temperature, then reset ages will never be observed at that point. The expansion limit of the reset area thus depends, ultimately, not on exhumation rate but on the material paths within the wedge. Because of the varying temperatures and depths relevant for different chronometers, this limiting state develops on different timescales for various thermochronological systems.

The third observable is the residence time of material in the wedge. Brandon and Vance [1992] argue that for the Cascadia region the presence of a contemporaneous volcanic source (the Cascade arc) ensures that the minimum zircon fission track age of an unreset sample closely approximates its depositional age. For the trench-basin turbidites of the Olympic subduction complex, with the rapid subduction of the Juan de Fuca Plate offshore of the Olympics ( $36 \mathrm{~mm}^{-1} \mathrm{r}^{-1}$ ), this depositional age can reasonably be equated with the timing of subduction and accretion of sediments into the wedge system [Brandon and Vance, 1992]. Unreset minimum ages can thus be used as a proxy for residence time in the wedge, which range from $39 \mathrm{Ma}$ in the east of the OSC to as low as $15 \mathrm{Ma}$ at the west coast of the Olympic Peninsula [Brandon and Vance, 1992; Brandon et al., 1998] (Figure 5).

The relative veractity of our models is judged on fit of these observables to measured thermochronological data across the Olympic Mountains (Figure 6). We use the reduced chi square statistic, $\chi_{r}{ }^{2}$ [Press et al., 1988]

$$
\chi_{r}^{2}=\left(\frac{1}{N-2}\right) \sum_{l} \frac{\left[\tau_{o_{1}}-\tau_{m}\left(x_{i}\right)\right]^{2}}{e_{o_{1}}},
$$

to judge the degree of fit of the model relative to the uncertainties of the each of the datasets, where $i$ is the ith sample at a distance $x_{i}$ landward from the deformation front, $\tau_{o}$ and $e_{o}$ are the observed isotopic age and its standard error, respectively, and $\tau_{m}\left(x_{l}\right)$ is the predicted model age at $x_{i}$ (Figure 6). Observed ages $\tau_{o}$ are projected onto the model transect and compared to model ages $\tau_{m}(x)$ at the corresponding locations (Figure 6). The fit is summarized for each of the three data sets (apatite fission tracks, zircon fission tracks, and apatite (U-Th)/He ages) by calculating the $\chi_{r}{ }^{2}$ value for the model age distribution. The calculated values of $\chi_{r}{ }^{2}$ are normalized by the number of degrees of freedom in each data set $(\mathrm{N}-2)$ to allow comparison between the different chronometers, despite the different number of ages for each data set. The best fit model is found by iterating models varying in $\alpha$ and $\dot{\varepsilon}_{\max }$ until $\chi_{r}{ }^{2}$ is minimized.

\subsection{Wedge Kinematics}

Mass balance calculations for the Cascadia margin at Vancouver Island [Clowes et al., 1987] suggest that most, if not all, of the sedimentary sequence on the incoming Juan de Fuca Plate is accreted into the wedge. This conclusion appears to hold over the long term as well. To the south of the Olympics in southwest Washington, the compositions of the recent Cascade Volcanics do not provide evidence for subducted sediment in their mantle source [Leeman et al., 1990]. Lack of sediment subduction would require full accretion of the Juan de Fuca sedimentary cover into the Cascadia wedge.

The mechanism by which this sediment is incorporated into the wedge, however, may vary significantly along the margin. To the north, offshore of Vancouver Island, the subduction thrust appears to cut deeply through the incoming sedimentary section, which implies that much or all of that section is being frontally accreted at present [Davis and Hyndman, 1989; Hyndman et al., 1990; Westbrook et al., 1994]. In contrast, along the western edge of the Oregon margin, landward dipping thrusts at the front of the wedge flatten out into a décollement lying approximately in the middle of the incoming sedimentary section at $2 \mathrm{~km}$ depth [Cochrane et al., 1994]. The implication is that the remaining sedimentary section is accreted at deeper levels beneath the wedge (Figure 3 ). Thus, the relative balance of frontal accretion and underplating of sedimentary material at the Olympic margin is an unknown variable that will have important implications for predicted material paths and thermal histories. Sediments accreted at the front of the wedge must pass through the entire wedge before exposure in the eroding forearc high. Such material thus experiences a markedly 2-D history. In contrast, deeply underplated sediments could, in the extreme, have a purely 1-D vertical exhumation history. This problem is investigated here using the parameter $\alpha$, the relative proportion of the sedimentary section incorporated into the wedge by frontal accretion. The remaining balance of the sedimenary budget $(1-\alpha)$ is assumed to be deeply underplated beneath the wedge. For the purposes of the scenarios considered here $\alpha$ is assumed to be time invariant.

For $\alpha=0$, where the entire sedimentary sequence is carried beneath the Cascadia wedge and underplated at depth, exhumation paths are purely vertical. The underplated material experiences a constant rate of exhumation during its residence in the wedge, corresponding to the erosion rate at the overlying surface point. This velocity field predicts that horizontal gradients in erosion rate are accommodated by related gradients in the vertical shear strain rate. For this end member, calculated reset ages are simply related to the erosion rate function (Figure $2 b$ ) by

$$
\tau_{m}(x)=\frac{z_{c}}{\dot{\varepsilon}(x)}
$$

where $z_{c}$ is the depth at which isotopic closure occurs for the relevant chronometer. The $\alpha=0$ model notably fails to satisfactorily account for the observed pattern of zircon fission track ages (Figure 6). The predicted ages of the reset zircon fission track samples are approximately correct (circa 12 to 14 $\mathrm{Ma}$ ), but the predicted position of the reset zircon fission track zone falls $30 \mathrm{~km}$ to the west of the observed zone (Figure 6) because the model erosion rates are highest to the west of the zircon reset zone. In contrast, the position and ages of the reset zone in the $\alpha=0$ model are reasonably well fit for both fission track and (U-Th)/He ages in apatite. This result illustrates an important feature of using multiple thermochronometers. Chronometers with high closure temperatures provide more information about the two-dimensional nature of the exhumation path, whereas the lower $T_{c}$ thermochronometers are less sensitive to lateral motion of material but provide better resolution of recent exhumation rates and surface processes. 

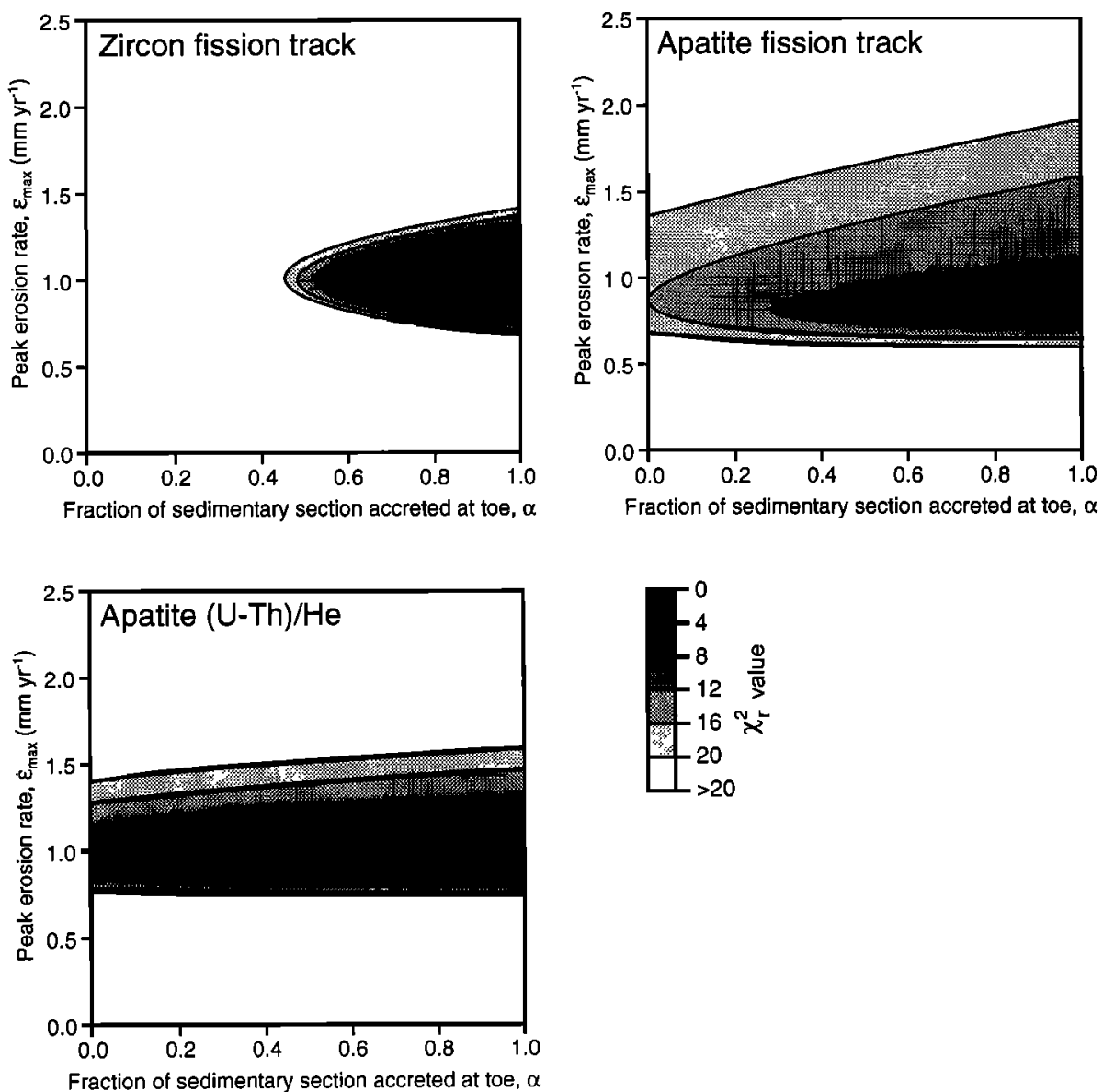

Figure 7. Relative model fit to thermochronological data, described by variation in $\chi_{r}{ }^{2}$ with $\alpha$ and $\dot{\varepsilon}_{\max }$.

The introduction of frontal accretion into the model affects the predicted distribution of ages in several ways (Figure 6). Toward the inland margin of the wedge, the rear no-flow boundary condition (Fig. 3b) results in particle motions that approach vertical, so there is little difference between age distributions predicted by different $\alpha$ values in that area. As horizontal motion becomes progressively more important toward the front of the wedge, (1) the location of the reset zone boundaries are moved landward by the horizontal motion and (2) material experiences a range of exhumation rates as it is advected through the laterally varying velocity field (Figure $2 \mathrm{~b}$ ). As a result, ages become a function of the average exhumation rate along the material path, rather than being indicative of erosion rates at any particular spatial point. The impact of these effects scales with the closure temperature of the relevant chronometer. Assuming identical kinematic conditions, higher-temperature thermochronometers integrate exhumation rates over a longer period and travel farther horizontally after closure than lower-temperature systems, prior to their eventual exposure at the surface.

Model sensitivity to this variation in accretion pathway is shown by the $x$ axis in Figure 7. Apatite (U-Th)/He ages display only minor response to $\alpha$ variation, due to the relatively low closure temperature for the system $\left(\sim 65^{\circ} \mathrm{C}\right)$, and the correspondingly short time interval over which any horizontal motions are integrated. Apatite fission track ages display somewhat higher sensitivity (Figure 7). Minor improvements in fit are observed for this system with increasing $\alpha$ due to improved fit to ages in the west of the orogen, with model residence times approaching the observed ages in this area (Figure 6). The sensitivity of this data set is limited by the high relative errors of apatite fission track ages from this region (Figure 5), which maintains $\chi_{r}{ }^{2}$ at high levels, even for relatively well-fit models.

The influence of $\alpha$ on model fit is strongest for zircon fission track ages. As $\alpha$ increases and lateral migration of material through the wedge becomes more significant, the reset zone for zircon fission track ages is progressively widened and pushed farther eastward (Figure 6), improving model fit to the observed age distribution (Figure 7). At a 95\% confidence level, optimal fit to the observed zircon fission track ages requires $\alpha>0.80$, and favors higher values of $\alpha$, up to 1.0.

\subsection{Flux Steady State}

On the basis of age-elevation trends and paired cooling ages from the Olympic Mountains, Brandon et al. [1998] suggest that long term erosion rates in the center of the Olympics have remained relatively constant since circa $14 \mathrm{Ma}$. This consistency indicates that erosion rates apparently reached modern levels within several million years following initial emergence of the forearc high at circa $18 \mathrm{Ma}$ [Brandon et al. . 1998]. Because of the influence of material flux balance on the deformation of an accretionary wedge [Barr and Dahlen, 1990], such an erosional steady state would also require a flux steady-state since $14 \mathrm{Ma}$ for the Olympics, where the rate of accretionary influx would balance the erosional outflux from the wedge. 


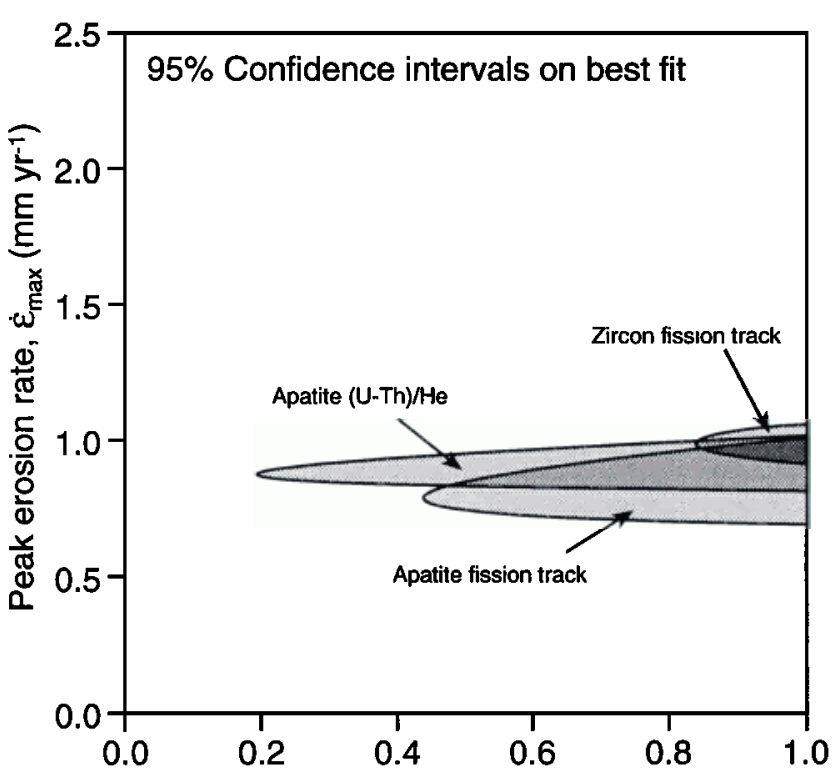

Fraction of sedimentary section accreted at toe, $\alpha$

Figure 8. Summary of conditions providing the best fit to the three thermochronological data sets considered. Best fit envelopes encompass a $95 \%$ confidence interval above the minimum $\chi_{r}{ }^{2}$ value obtained for each data set. Overlap of best fit domains is indicated by sequential darkening.

We test the applicability of this flux steady state hypothesis through the combined analysis of the three available thermochronological datasets. Closure of these chronometers occurs at a variety of temperatures: $\sim 65^{\circ} \mathrm{C}$ for $(\mathrm{U}-\mathrm{Th}) / \mathrm{He}$ and $\sim 100^{\circ} \mathrm{C}$ for fission tracks in apatite, and $240-260^{\circ} \mathrm{C}$ for zircon fission tracks. The three thus close at varying depths in the wedge, with their ages integrating exhumational histories after closure over different time spans.

As discussed in section 3, the basic distribution of erosion rates across the Olympics appears to reflect the topography and orographic rainfall patterns of the Olympic Mountains, with erosion highest on the wet ocean-facing western side of the massif [Pazzaglia and Brandon, 2001]. Assuming that this geographic influence has been consistent throughout the history of the orogen, we take the form (but not the amplitude) of the erosion function as a constant, with peak rates in the west of the Olympic Peninsula decreasing to zero at either coast (Figure 2b). We then vary $\dot{\varepsilon}_{\max }$ and assess the resulting fit of the model. By minimizing $\chi_{r}{ }^{2}$ for each data set in this analysis, we find the best fitting conditions for the orogen on a range of timescales. If the Olympic Mountains have been in a flux steady state since 14 $\mathrm{Ma}$ (the oldest reset zircon fission track age from the massif), then the varying timescale of the chronometers should be irrelevant, and all three data sets should be consistent with a single set of erosion rates.

All three thermochronometers display high sensitivity to $\dot{\varepsilon}_{\max }$ (Figure 7). At a 95\% confidence interval (Figure 8), the optimal fits of the three systems overlap for peak erosion rates of $\sim 0.9-1.0$ $\mathrm{mm} \mathrm{yr}^{-1}$. The hypothesized flux steady state is thus consistent with the available data. Such a fit is notable in the context of the marked climatic variation and oscillation of glacial and interglacial conditions during the late Cenozoic [e.g., Mathewes et al., 1993; Booth, 1994; Peizhen et al., 2001]. The evidence of consistent erosion rates suggests that at least on the million-year timescale relevant to the chronometers considered here, tectonic uplift, and not climate, is forcing erosion. Such tectonic control would require the limiting factor in the landscape evolution to be

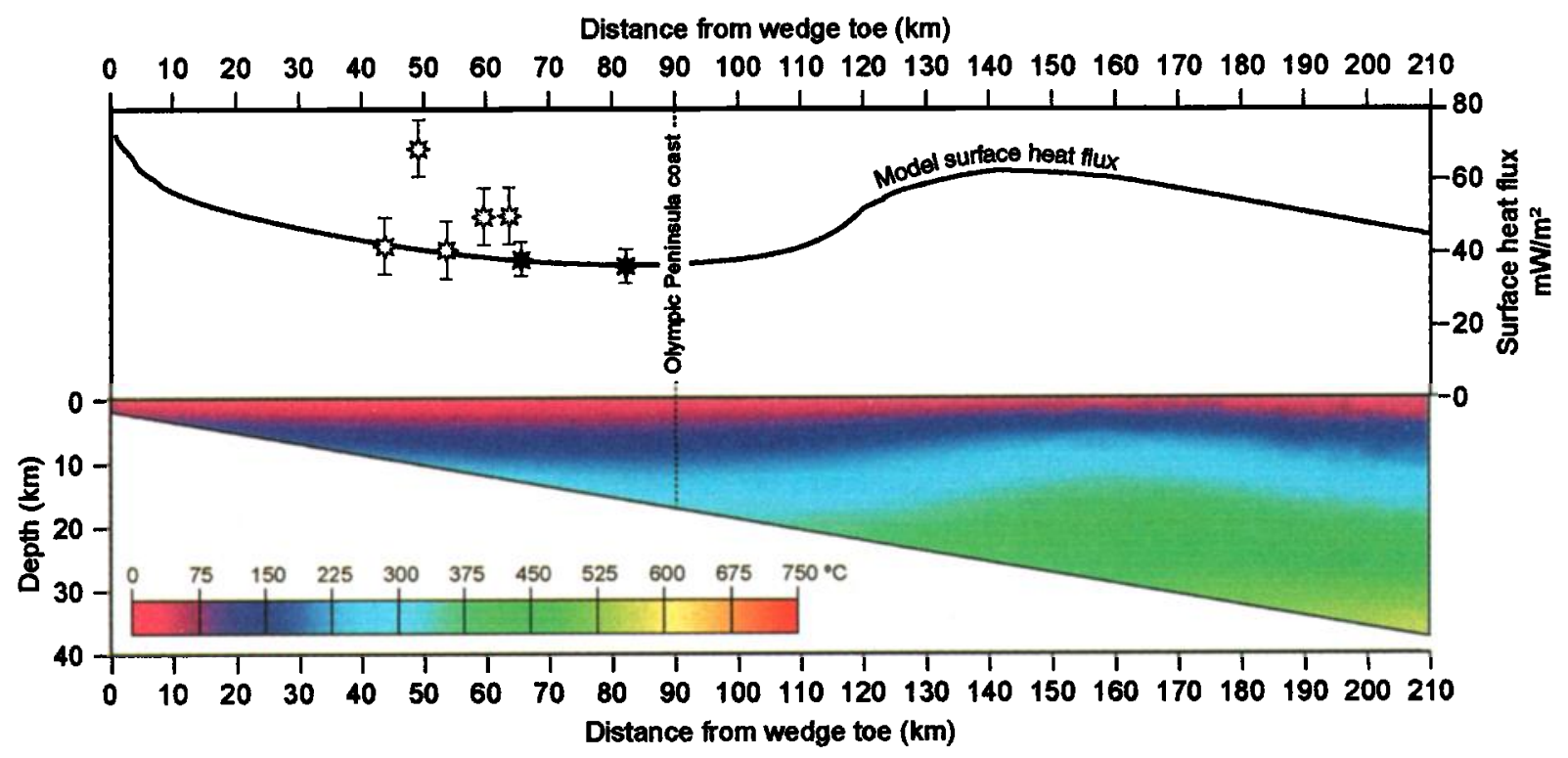

Plate 2. Predicted thermal structure and surface heat flow of our overall best fit model $\left(\dot{\varepsilon}_{\max }=0.95 \mathrm{~mm} \mathrm{yr}^{-1}, \alpha=1.0\right)$. Heat flow measurements from southwest of Vancouver Island (shaded stars) [Lewis et al., 1988] and coastal Washington (solid stars) [Blackwell et al., 1990] are projected into the section using the relative location of the Cascadia subduction zone as a datum. Lewis et al. [1988] attribute much of the variability between the tightly clustered wells off Vancouver Island to local thermal effects or fluid movement, rather than spatial variations in deeper heat flux, and thus only general trends can probably be drawn from them. The Lewis et al. [1988] data should also be regarded as heat flow maxima here because of the younger age (8 Ma compared to $9 \mathrm{Ma}$ ) and consequently higher temperature of the subducting Juan de Fuca Plate off Vancouver Island, relative to the Olympic Peninsula 
insensitive to climatic conditions. Bedrock landsliding, as an example, may satisfy this requirement. As long as sediment transport rates are sufficient to remove the evolved debris, landform evolution and erosion in an environment controlled by bedrock landsliding are insensitive to further variation in climate and become dominated instead by uplift and the development of steep slopes [e.g., Hovius et al., 1997, 1998]. Note that our age data are insensitive to the shorter timescale effects of climate variation (e.g., the $\sim 100 \mathrm{kyr}$ glacial cycle). Such climatic variations will undoubtedly produce cyclic variations in erosion rates. Our modeling results provide only an averaged measure of rates on longer timescales and indicate that on average, the erosion rates in the Olympics have remained steady, even with the onset of Quatemary "icehouse" conditions.

The predicted thermal structure and surface heat flow of our best fit model (with an erosion rate of $0.95 \mathrm{~mm} \mathrm{yr}^{-1}$, and $\alpha=1.0$ ) are shown in Plate 2. In the submarine portion of the wedge the dominant heat source is the young, hot subducting Juan de Fuca Plate. With the eastward thickening of the accreted Cascadia wedge sediments progressively insulating this heat source, model surface heat flux steadily decreases landward from $\sim 75 \mathrm{~mW} \mathrm{~m}^{-2}$ at the Cascadia subduction zone to $40 \mathrm{~mW} \mathrm{~m}^{-2}$ at the west coast of the Olympic Peninsula. Across the Olympic Peninsula, surface heat flow then increases sharply again to $\sim 60 \mathrm{~mW} \mathrm{~m}^{-2}$ over a distance of $50 \mathrm{~km}$ before tapering off to $45 \mathrm{~mW} \mathrm{~m}^{-2}$ at the east coast (Plate 2). This asymmetric heat flux high is centered over the high topography of the Olympic Mountains and approximately parallels the variation in erosion rate across the orogen (Figure $2 b$ ). This correlation is due to advection of heat by exhumation. Heat flow measurements made in exploration wells offshore of Vancouver Island [Lewis et al., 1988] and Oregon [Blackwell et al., 1990] are shown projected into the model section. Despite their relatively high uncertainty (conservatively estimated at $\sim 20 \%$ by Lewis et al. [1988]) these data support our assertion that the background thermal structure of the model adequately represents the thermal conditions of the offshore Cascadia wedge (Plate 2). No surface heat flow measurements are available from the exhumed interior of the Olympic Mountains, so that despite its potential as an indicator of kinematics and thermal structure, this variable cannot be used to directly constrain the model.

\section{Conclusions}

The two-dimensional model described here produces a thermal structure and model distributions for zircon and apatite fission track ages and apatite ( $\mathrm{U}-\mathrm{Th}) / \mathrm{He}$ ages comparable to those observed in the Olympic Mountains segment of the Cascadia wedge. The success of the model is assessed with reference to the degree to which these model and observed age profiles concur. Variation in model fit with changing accretionary and erosional fluxes indicates that most, and possibly all, of the sedimentary section on the subducting Juan de Fuca Plate is incorporated into the Cascadia wedge seaward of the Olympic Peninsula by frontal accretion at or near the wedge toe. The thermal and exhumational histories experienced by material passing through the wedge are thus sensitive to the convergent component of motion. Material accreted at the front must pass horizontally through a large part of the deforming wedge prior to its eventual exhumation in the forearc high at the rear of the wedge, and accreted materials experience an accompanying range of thermal and erosional conditions during their passage. Two-dimensional models, such as those developed here, are desirable in this setting to place the physical interpretation of thermochronological data in a valid kinematic context.

The variety of isotopic age systems available for the Olympic Mountains provide insight into the evolution of the wedge over a variety of timescales, ranging from Pleistocene (2-3 Ma) for (U$\mathrm{Th}) / \mathrm{He}$ ages in apatite to late Miocene ( $7 \mathrm{Ma}$ ) for fission tracks in apatite and to early Miocene (13-14 Ma) for fission tracks in zircon. The earliest of these constraints occurred not long after the initial subaerial exposure of the Olympic Peninsula at circa 18 Ma. Our model results support the hypothesis that the wedge has been in a flux steady state since circa $14 \mathrm{Ma}$, with the accretionary flux into the wedge balanced by an erosional flux from the subaerial forearc high. This indicates that climatic variation over this interval has not played a significant role in the overall uplift and erosion of the massif. These characteristics must be controlled by tectonic rather than climatic conditions for the Olympic Mountains, at least on the timescales relevant to thermochronologic data. The apparent balance of accretionary and erosional fluxes in our models is consistent with the argument that margin-parallel transport along the Cascadia Margin has not played a significant role in the development of the Olympic Mountains [e.g. Brandon et al., 1998; Pazzaglia and Brandon, 2001].

Acknowledgments. This work was completed while G.B. was funded by a Damon Wells post doctoral fellowship at Yale University. Detailed and thorough reviews of this manuscript by Peter Reiners and Phil Armstrong helped to significantly improve the clarity of our arguments.

\section{References}

Armstrong, R., and P. L. Ward, Evolving geographic patterns of Cenozoic magmatism in the North American Cordillera: the temporal and spatial association of magmatism and metamorphic core complexes, $J$. Geophys. Res., 96, 13,201-13,224, 1991.

Babcock, R. S., R. F. Burmester, D. C. Engebretson, A. Warnock, and K. P. Clark, A rifted margin origin for the Crescent basalts and related rocks in the northern Coast Range volcanic province, Washington and British Columbia, J. Geophys. Res., 97, 6799-6821, 1992.

Barr, T. D., and F. A. Dahlen, Constraints on friction and stress in the Taiwan fold-and-thrust belt from heat flow and geochronology, Geology, 18, 111-115, 1990.

Batt, G. E., and J. Braun, On the thermo-mechanical evolution of compressional orogens, Geophys. J. Int., 128, 364-382, 1997.

Beaumont, C., P. J. J. Kamp, J. Hamilton, and P. Fullsack, The continental collision zone, South Island, New Zealand: Comparison of geodynamical models and observations, J. Geophys. Res., 101, 33333359, 1996.

Beck, M. E. Jr., Case for northward transport of Baja and coastal southern California; Paleomagnetic data, analysis, and alternatives, Geology, 19, 506-509, 1991.

Blackwell, D. D., J. L. Steele, S. Kelley, and M. A. Korosec, Heat flow in the state of Washington and thermal conditions in the Cascade Range, J. Geophys. Res., 95, 19,495-19,516, 1990.

Booth, D. B., Glaciofluvial infilling and scour of the Puget Lowland, Washington, during ice-sheet glaciation, Geology, 22, 695-698, 1994.

Brandon, M. T., and A. R. Calderwood, High-pressure metamorphism and uplift of the Olympic subduction complex, Geology, 18, 1252$1255,1990$.

Brandon, M. T., and J. A. Vance, Tectonic evolution of the Cenozoic Olympic subduction complex, Washington State, as deduced from fission track ages for detrital, Am. J. Sci., 292, 565-636, 1992.

Brandon, M. T., M. K. Roden-Tice, and J. I. Garver, Late Cenozoic exhumation of the Cascadia wedge in the Olympic Mountains, northwest Washington State, Geol. Soc. Am. Bull., 110, 985-1009, 1998.

Carslaw, H. S., and J. C. Jaeger, Conduction of Heat in Solids, 510 pp., Oxford Univ. Press, New York, 1959. 
Clark, S. P., and E. Jäger, Denudation rates in the Alps from geochronologic and heat flow data, Am. J. Sci., 267, 1143-1160, 1969.

Clowes, R. M., M. T. Brandon, A. G. Green, C. J. Yorath, A. Sutherland Brown, E. R. Kanasewich, and C. Spencer, LITHOPROBE-Southern Vancouver Island: Cenozoic subduction complex imaged by deep seismic reflections, Can. J. Earth Sci., 24, 31-51, 1987.

Cochrane, G. R., M. E. MacKay, G. F. Moore, and J. C. Moore, Consolidation and deformation of sediments at the toe of the central Oregon accretionary prism from multichannel seismic data, Proc. Ocean Drill. Program Part A Initial Rep., 146, 421-426, 1994.

Crowley, K. D., Mechanisms and kinetics of apatite fission-track annealing; discussion, Am. Mineral., 78, 210-212, 1993.

Dahlen, F. A., and J. Suppe, Mechanics, growth, and erosion of mountain belts, in Processes in contmental lithospheric deformation, edited by S. P. Clark Jr., B. C. Burchfiel, and J. Suppe, Spec. Pap. Geol. Soc. Am. 218, 161-178, 1988.

Davis, E. E., and R. D. Hyndman, Accretion and Recent deformation of sediments along the northern Cascadia subduction zone, Geol. Soc. Am. Bull., 10I, 1465-1480, 1989.

Davis, E. E., R. D. Hyndman, and $H$. Villinger, Rates of fluid expulsion across the northern Cascadia accretionary prism; constraints from new heat flow and multichannel seismic reflection data, J. Geophys. Res., 95, 8869-8889, 1990

DeMets, C., and T. Dixon, New kinematic models for Pacific-North America motion from $3 \mathrm{Ma}$ to present, I, Evidence for steady motion and biases in the NUVEL-1A model, Geophys. Res. Lett., 26, 19211924, 1999.

DeMets, C., R. G. Gordon, D. F. Argus, and S. Stein, Current plate motions, Geophys. J. Int., 10l, 425-478, 1990.

Devoe, V. H., W. Holt, and A. J. Haines, Kinematics of northern South Island, New Zealand, Eos Trans $A G U, 73$ (43), Fall Meet. Suppl., 124, 1992.

Dickinson, W. R., and D. R. Seely, Structure and stratigraphy of forearc regions, $A A P G$ Bull., 63, 2-31, 1979.

Dodson, M. H., Theory of cooling ages, in Lectures in Isotope Geology, edited by E. Jaeger and J. C. Hunziker, pp 194-202, Springer-Verlag, New York, 1979.

Doherty, J. T., and J. B. Lyons, Mesozoic erosion rates in northern New England, Geol Soc. Am. Bull., 91, I16-I20, 1980.

Duddy, I. R., P. F. Green, and G M. Laslett, Thermal annealing of fission tracks in apatite, 3, Variable temperature behaviour, Chem. Geol., 73, 25-38, 1988.

Dumitru, T. A., Effects of subduction parameters on geothermal gradients in forearcs, with an application to Franciscan subduction in California, J. Geophys. Res, 96, 621-641, 1991.

Engebretson, D. C., R. G. Gordon, and A. Cox, Relative motions between oceanic and continental plates in the Pacific basin, Spec. Pap. Geol. Soc Am. 206, 59 pp., 1985.

Farley, K. A., Helium diffusion from apatite: general bevavior as illustrated by Durango fluorapatite, J. Geophys Res., 105, 2903-2914, 2000.

Farley, K. A., R. A. Wolf, and L. T. Silver, The effects of long alphastopping distances on (U-Th)/He dates, Geochim Cosmochim. Acta 60, 4223-4230, 1996.

Fisher, M. A., E. R. Flueh, D. W. Scholl, T. Parsons, R. E. Wells, A. Trehu, U. ten Brink, and C. S. Weaver, Geologic processes of accretion in the Cascadia subduction zone west of Washington State, Geodynamics, 27, 277-288, 1999.

Fleischer, R. L., and P. B. Price, Techniques for geological dating of minerals by chemical etching of fission fragment tracks, Geochim. Cosmochim. Acta, 28, 1705-1714, 1964.

Foster, D. A., B. P. Kohn, and A. J. W. Gleadow, Sphene and zircon closure temperatures revisited: Empirical calibrations from ${ }^{40} \mathrm{Ar} /{ }^{39} \mathrm{Ar}$ diffusion studies of K-feldspar and biotite, paper presented at International Workshop on Fission Track Dating, University of Gent, Ghent, Belgium, 1996.

Galbraith, R. F., Graphical display of estimates having different standard errors, Technometrics, 30, 271-281, 1988.

Galbraith, R. F., and P. F. Green, Estimating the component ages in a finite mixture, Nucl. Tracks Radiat. Meas., 2I, 197-206, 1990.

Garver, J. I., and M. T. Brandon, Erosional denudation of the British Columbia Coast Ranges as determined from fission-track ages of detrital zircon from the Tofino Basin, Olympic Peninsula, Washington, Geol. Soc. Am. Bull, J06, 1398-1412, 1994.

Green, P. F., The relationship between track shortening and fission-track age reduction in apatite: Combined influences of inherent instability annealing anisotropy, and length bias and system calibration, Earth Planet. Sci. Lett., 89, 335-352, 1988.

Heller, P. L., R. W. Tabor, and C. A. Suczek, Paleogeographic evolution of the United States Pacific Northwest during Paleogene time, Can. J. Earth Sci., 24, 1652-1667, 1987.

Holt, W., The active tectonics, and lithospheric structure of Tibet, southeast China, and Burma, in New Zealand Geology and Geophysics Conference, Misc. Publ. 43, p. 51, Geol. Soc. N. Z., Dunedin, 1989.

House, M. A., B. P. Wernicke, K. A. Farley, and T. A. Dumitru, Cenozoic thermal evolution of the central Sierra Nevada, California, from (UTh)/He thermochronometry, Earth Planet. Sci. Lett., 151, 167-179, 1997.

Hovius, N., C. P. Stark, and P. A. Allen, Sediment flux from a mountain belt derived by landslide mapping, Geology, 25, 231-234, 1997

Hovius, N., C. P. Stark, M. A. Tutton, and L. D. Abbott, Landslide-driven drainage network evolution in a pre-steady-state mountain belt; Finisterre Mountains, Papua New Guinea, Geology, 26, 1071-1074, 1998.

Hurley, P. M., H. Hughes, W. H. Pinson Jr., and H. W. Fairbairn, Radiogenic argon and strontium diffusion parameters in biotite at low temperatures obtained from Alpine Fault uplift in New Zealand, Geochim. Cosmochim. Acta, 26, 67-80, 1962.

Hyndman, R. D., and K. Wang, Thermal constraints on the zone of major thrust earthquake failure: The Cascadia subduction zone, $J$. Geophys. Res., 98, 2039-2060, 1993.

Hyndman, R. D., and K. Wang, The rupture zone of Cascadia great earthquakes from current deformation and the thermal regime, $J$. Geophys. Res., 100, 22,133-22,154, 1995.

Hyndman, R. D., C. J. Yorath, R. M. Clowes, and E. E. Davis, The northern Cascadia subduction zone at Vancouver Island: Seismic structure and tectonic history. Can. J. Earth Scl., 27, 313-329, 1990.

Hyndman, R. D., K. Wang, T. Yuan, and G. D. Spence, Tectonic sediment thickening, fluid expulsion, and the thermal regime of subduction zone accretionary prisms: The Cascadia margin off Vancouver Island, J. Geophys Res., 98, 21,865-21,876, 1993.

Jamıeson, R. A., C. Beaumont, J. Hamilton, and P. Fullsack, Tectonic assembly of inverted metamorphic sequences, Geology, 24, 839-842. 1996.

Kasuya, M., and C. W. Naeser, The effect of alpha-damage on fissiontrack annealıng in zircon, Nucl. Tracks Radiat. Meas., 14, 477-480, 1988.

Kulm, L. D., et al., Western North American Continental margin and adjacent ocean floor off Oregon and Washıngton, Ocean Margin Drill Program Reg. Allas Ser., vol. 1, 32 pp., Mar. Sci. Int, Woods Hole, Mass., 1984

Laslett, G. M., P. F. Green, I R. Duddy, and A. J. W. Gleadow, Thermal annealıng of fission tracks in apatite, Chem. Geol., 65, 1-13. 1987.

Leeman, W. P., D. R. Smith, W. Hildreth, Z. Palacz, and N Rogers, Compositional diversity of late Cenozoic basalts in a transect across the southern Washington Cascades: Implications for subduction zone magmatism, J. Geophys. Res, 95, 19,561-19,582, 1990.

Lewis, T. J., W. H. Bentowski, E. E. Davis, R. D. Hyndman, J. G Souther, and J. A. Wright, Subduction of the Juan de Fuca plate: Thermal consequences, J. Geophys. Res., 93, 15,207-15,225, 1988.

Lonsdale, P. F., Paleogene history of the Kula Plate: Offshore evidence and onshore implications. Geol. Soc. Am. Bull., 100, 733-754, 1988.

MacKay, M. E., Structural variation and landward vergence at the toe of the Oregon accretionary prism, Tectonics, 14, 1309-1320, 1995.

Mathewes, R. W., L. E. Heusser, and T. R. Patterson, Evidence for a Younger Dryas-lıke cooling event on the Britısh Columbia coast, Geology, 21, 101-104, 1993.

McCaffrey, R., Estimates of modern arc-parallel strain rates in fore arcs, Geology, 24, 27-30, 1996.

McCaffrey, R., and C Goldfinger, Forearc deformation and great subduction earthquakes; implications for Cascadia offshore earthquake potential, Science. 267, 856-859, 1995

McCrory, P.A., Tectonic model explaining divergent contraction directions along the Cascadia subduction margin, Washington, Geology, 24, 929-932, 1996.

Molnar, P., and P. England, Temperatures in zones of steady-state underthrusting of young oceanic lithosphere, Earth Planet. Sct. Lett., 131, 57-70. 1995.

Moran, J. E., and C. R. B. Lister, Heat flow across Cascadia Basin near $47^{\circ} \mathrm{N}, 128^{\circ} \mathrm{W}, J$. Geophys. Res., 92, 11,416-11,432, 1987. 
Oxburgh, E., Heat tlow and magma genesis, in Physics of Magmatic Processes, edited by R. Hargraves, pp. 161-200, Princeton Univ. Press, Princeton, N. J., 1980.

Oxburgh, E., and N. Wilson, Temperature, fluid flow, and hydrocarbon maturation, in CRC Handbook of Seafloor Heat Flow, edited by J. Wright and K. Louden, pp. 191-229, CRC Press, Boca Raton, Fla., 1989.

Pazzaglia, F. J., and M. T. Brandon, A fluvial record of long-term steadystate uplift and erosion across the Cascadia forearc high, western Washington State, Am. J. Scl., 301, 385-431, 2001.

Peizhen, Z., P. Molnar, and W.R. Downs, Increased sedimentation rates and grain sizes 2-4 Myr ago due to the influence of climate change on erosion rates, Nature, 410, 891-897, 2001.

Press, W. H., B. P. Flannery, S A. Teukolsky, and W. T. Vetterling, Numerical Recipes: The Art of Scientific Computing, 818 pp., Cambridge Univ. Press, New York, 1988.

Price, P. B., and R. M. Walker, Observation of fossil particle tracks in natural micas, Nature, 196, 732-734. 1962.

Price, P. B., and R. M. Walker, Fossil tracks of charged particles in mica and the age of minerals, J. Geophys. Res., 68, 4847-4862, 1963.

Price, P. B., R. L. Fleischer, D. S. Miller, and E. S. Symes, Fossil charged-particle tracks and mineral ages, Spec. Pap. Geol. Soc. Am., I33, 1964.

Rau, W. W., Geology of the Washington coast between Point Grenville and the Hoh River, Bull. 66, 58 pp., Wash. Dep. Nat. Resour., Geol. and Earth Resour. Div., Olympia, 1973.

Sardarov, S. S., Sokhrannost radiogennogo argona v mikroklinakh. Geokhimya, 3, 193-197, 1957.

Sherrod, D. R., and J. G. Smith, Quaternary extrusion rates from the Cascade Range, northwestern United States and British Columbia, in Proceedings of Workshop XLIV; Geological, Geophysical, and Tectonic Setting of the Cascade Range, edited by L. J. P. Muffler, C. S. Weaver, and D. D. Blackwell, compiled by M. L. Jacobson, U.S. Geol. Surv. Open File Rep., 94-103, 1989.

Smith, J. G., Western Cascades, southern Oregon and northern California, in Volcanism and Plutonism of Western North America; vol. 1, South Cascades Arc Volcanism, Callfornia and Southern Oregon, Field Trip Guideb., vol. T312, edited by L. J. Muffler et al., pp. 37-42, AGU, Washington, D. C., 1989.

Snaveley, P. D., Jr., Tertiary geologic framework, neotectonics, and petroleum potential, in Geology and Resource Potential of the Continental Margin of Western North America and Adjacent Ocean Basins - Beaufort Sea to Baja Califormia, Earth Sci. Ser., vol. 6, pp. 305-335, edited by D. W. Scholl, A. Grantz, and J. G. Vedder, Circum-Pac. Counc. for Energy and Miner. Resour., Houston, Tex., 1987.

Stewart, R. J., Petrology, metamorphism and structural relations of graywackes in the western Olympic Peninsula, Washington, Ph.D. dissertation, 129 pp., Stanford Univ., Stanford, Calif., 1970.

Tabor, R. W., and W. H. Cady, Geologic map of the Olympic Peninsula, U. S. Geol. Surv. Map, I-994, scale 1:250 000, 1978a.

Tabor, R. W., and W. H. Cady, The structure of the Olympic Mountains, Washington - Analysis of a subduction zone, U. S. Geol. Surv. Prof. Pap., 1033. 38 pp., $1978 \mathrm{~b}$.
Tagami, T., H. Ito, and S. Nishimura, Thermal annealing characteristics of spontaneous fission tracks in zircon, Chem. Geol., 80, 159-169, 1990.

Wang, C. Y., G. Liang, and Y. Shi, Heat flow across the toe of accretionary prisms: The role of fluid flux, Geophys. Res. Lett., 20. 659-662, 1993.

Wang, K., Simplified analysis of horizontal stresses in a buttressed forearc sliver at an oblique subduction zone, Geophys. Res. Lett., 23, 2021-2024, 1996.

Wang, K., T. Maulder, G. C. Rodgers, and R. D. Hyndman, Case for very low coupling stress on the Cascadia subduction fault, J. Geophys. Res., 100, 12,907-12,918. 1995.

Wells, R. E., D. C. Engebretson, P. D. Snaveley Jr., and R. S. Coe, Cenozoic plate motions and the volcano-tectonic evolution of western Oregon and Washington, Tectonics, 3, 275-294. 1984.

Westbrook, G. K. et al., Summary of Cascadia drilling results, Proc. Ocean Drill. Program Part A Initial Rep., 146, 389-396, 1994.

Willett, S. D., Inverse modeling of annealing of fission tracks in apatite 1: A controlled random search method, Am. J. Sci., 297, 939-969, 1997.

Willett, S., C. Beaumont, and P. Fullsack, Mechanical model for the tectonics of doubly vergent compressional orogens, Geology, 21, 371374, 1993.

Wilson, D. S., Tectonic history of the Juan de Fuca Ridge over the last 40 million years, J. Geophys. Res., 93, 11,863-11,876, 1988.

Wolf, R. A., K. A. Farley, and L. T. Silver, Helium diffusion and lowtemperature thermochronometry of apatite, Geochim. Cosmochim. Acta, 60, 4231-4240, 1996.

Yamada, R., T. Tagami, S. Nishimura, and H. Ito, Annealing kinetics of fission tracks in zircon; an experimental study, Chem. Geol., 122, 249258, 1995.

Yorath, C. J., A. G. Green, R. M. Clowes, A. S. Brown, M. T. Brandon, E. R. Kanasewich, R. D. Hyndman, and C. Spencer, Lithoprobe, southern Vancouver Island; Seismic reflection sees through Wrangellia to the Juan de Fuca Plate, Geology, 13, 759-762, 1985.

Yuan, T., G. Spence, and R. Hyndman, Seismic velocities and inferred porosities in the accretionary wedge sediments at the Cascadia margin, $J$ Geophys. Res., 99, 4413-4427, 1994.

Zaun, P. E., and G. A. Wagner, Fission track stability in zircons under geological conditions, Nucl Tracks Radiat. Meas., 10, 303-307, 1985.

G. E. Batt, Geology Department, Royal Holloway University of London, Egham, Surrey, TW20 0EX, UK. (g.batt@gl.rhul.ac.uk)

M. T. Brandon, Department of Geology and Geophysics, Yale University, P. O. Box 208109, New Haven, CT 06520-8109, USA. (mark.brandon@yale.edu).

K. A. Farley, Division of Geological and Planetary Sciences, California Institute of Technology, MS 170-25, 391 S. Holister Ave., Pasadena, CA 91125, USA. (farley@gps.caltech.edu).

M. Roden-Tice, Center for Earth and Environmental Science, SUNY at Plattsburgh, Hudson 102, Plattsburgh, NY 12901, USA.

(Received August 10, 2000; revised March 9, 2001; accepted April 25, 2001.) 